\title{
Recrutar. Produzir. Abastecer: repensar a produção e o comércio agrícolas em tempo de guerras (1369-1400)
}

\section{Leandro Ribeiro Ferreira}

\section{(2) OpenEdition Journals}

Edição electrónica

URL: http://journals.openedition.org/medievalista/1117

DOI: 10.4000/medievalista. 1117

ISSN: 1646-740X

Editora

Instituto de Estudos Medievais - FCSH-UNL

\section{Refêrencia eletrónica}

Leandro Ribeiro Ferreira, «Recrutar. Produzir. Abastecer: repensar a produção e o comércio agrícolas em tempo de guerras (1369-1400) », Medievalista [Online], 18| 2015, posto online no dia 01 junho 2015, consultado o 16 março 2020. URL : http://journals.openedition.org/medievalista/1117 ; DOI : https://doi.org/10.4000/medievalista.1117

\section{(c) (7) (5)}

Mediavalista está licenciado com uma Licença Creative Commons - Atribuição-NãoComercial 4.0 Internacional. 
Título: Recrutar. Produzir. Abastecer : repensar a produção e o comércio agrícolas em tempo de guerras (1369-1400)

Autor(es): Leandro Ribeiro Ferreira

Universidade: Universidade do Porto

Faculdade e Departamento / Unidade de Investigação: Faculdade de Letras da Universidade do Porto / Departamento de História e de Estudos Políticos e Internacionais Código Postal: 4150-564

Cidade: Porto

País: Portugal

Contacto: leandro10dazuis@gmail.com | up090704065@letras.up.pt

Fonte: Medievalista [Em linha]. Dir. José Mattoso. Lisboa: IEM.

Disponível em:

http://www2.fcsh.unl.pt/iem/medievalista/MEDIEVALISTA18/ferreira1807.html

ISSN: 1646-740X

Data recepção do artigo: 24 de Novembro de 2014

Data aceitação do artigo: 17 de Abril de 2015

\section{Resumo}

Este artigo procura estudar a produção e o comércio agrícolas possuindo como pano de fundo os enfrentamentos bélicos vivenciados em Portugal entre 1369 e 1400. Nesta narrativa serão apresentadas as cicatrizes que seguiam no encalço da guerra, enquanto procuro repensar algumas questões da historiografia portuguesa sobre a produção e o comércio agrícolas destes tempos, nomeadamente a especulação de preços, as crises agrárias e as fomes, concluindo, por fim, numa análise às causas que estiveram na origem da promulgação da Lei das Sesmarias, em 1375, por D. Fernando. 
Palavras-chave: Produção agrícola; comércio agrícola; crises agrárias; Lei das Sesmarias; Idade Média.

\section{Abstract}

The aim of this paper is to study the agricultural production and its trade in the context of Portuguese wars between 1369 and 1400. This narrative will present the scars of the war in Medieval Portugal, while I seek to rethink some Portuguese historiograpic topics related with agricultural production and its trade in these times, namely price speculation, agrarian crisis and famines, concluding with an analysis to the Lei das Sesmarias promulgation, in 1375, by Dom Fernando.

Keywords: Agricultural production; agricultural trade; agrarian crisis; Lei das Sesmarias; Middle Ages. 


\section{Recrutar. Produzir. Abastecer: repensar a produção e o comércio agrícolas em tempo de guerras (1369-1400)}

\section{Leandro Ribeiro Ferreira}

\section{Introdução}

O trabalho de A. H. de Oliveira Marques no âmbito da história económica portuguesa ainda merece ser louvado. No estado atual da investigação algumas das suas asserções sobre a produção agrícola não foram verdadeiramente testadas e possuem algum do seu vigor $^{1}$. Segundo aquele autor, para se poder pensar em história da produção é necessário considerar um conjunto de fatores: clima, solo, mão-de-obra, produtos, tecnologia, propriedade, administração, produção animal, pesca, mineração, mesteres e sua organização, bem como a sua interligação com a circulação e distribuição (redes viárias terrestres e marítimas, pesos e medidas, mercados, comércio externo, consumo e níveis de vida $)^{2}$. Para além disso, para este autor o papel das estruturas era tão importante que alguns dos aspetos da produção agrícola medieval pertencem ${ }^{3}$ «mais à geografia

1 BARATA, Filipe Themudo e HENRIQUES, António Castro - "Economic and Fiscal History". in MATTOSO, José (dir.) - The Historiography of Medieval Portugal. Lisboa: Instituto de Estudos Medievais, Universidade Nova de Lisboa, 2011, p. 270.

${ }^{2}$ MARQUES, A. H. de Oliveira - "Ideário para uma história económica da Idade Média". in Ensaios de História Medieval Portuguesa. 2a ed. Lisboa: Veja, 1979, pp. 23-48.

${ }^{3}$ BARATA, Filipe Themudo e HENRIQUES, António Castro - "Economic and Fiscal History"..., p. 262. 
humana do que à história económica» ${ }^{4}$. Sobre a investigação na área da distribuição medieval, Oliveira Marques esboçou uma proposta contendo quatro pontos fundamentais: transporte e comunicações; comércio interno e externo; moeda e preços, pesos e medidas, e, finalmente, consumo ${ }^{5}$. No entanto, investigar separadamente a produção e a distribuição agrícolas pode levar a que se ignore as relações criadas entre ambas. De facto, se nos focarmos na inelasticidade dos recursos naturais, ao mesmo tempo que relegamos os mercados para um papel secundário, arriscamos a que este programa de investigação contenha um modelo Malthusiano implícito ${ }^{6}$. Será, portanto, pertinente estudar a produção agrícola medieval tendo como horizonte presente os dados registados sobre o comércio agrícola, quer em arquivos nacionais, quer em arquivos estrangeiros ${ }^{7}$.

Mas é nas mais recentes teorias que têm surgido na bibliografia estrangeira que devemos aportar a nossa análise, tentando renovar os questionários com que partimos para as fontes documentais portuguesas. Num artigo de reflexão, Luís Miguel Duarte

${ }^{4}$ MARQUES, A. H. de Oliveira - Introdução à História da Agricultura em Portugal: a questão cerealifera durante a Idade Média. 3. a ed. Lisboa: Edições Cosmos, 1978, p. 51.

5 MARQUES, A. H. de Oliveira - "Cidades Medievais Portuguesas (Algumas Bases Metodológicas Gerais)". in Revista de História Económica e Social. Lisboa. 9 (1982), p. 4.

${ }^{6}$ BARATA, Filipe Themudo e HENRIQUES, António Castro - "Economic and Fiscal History"..., p. 262.

${ }^{7}$ Sobre este último ponto, veja-se, por exemplo, alguns trabalhos bastante pertinentes: BARATA, Filipe Themudo - Navegação, Comércio e Relações Políticas: os Portugueses no Mediterrâneo Ocidental (1385-1466). Lisboa: Fundação Calouste Gulbenkian, 1998; MELO, Arnaldo - Trabalho e Produção em Portugal na Idade Média: O Porto, c. 1320 - c. 1415. 2 vols. Braga: Dissertação de doutoramento apresentada à Universidade do Minho e à École des Hautes Études en Sciences Sociales, 2009; DOMINGUEZ, Rodrigo da Costa - Mercadores e Banqueiros: Sociedade e Economia no Portugal dos Séculos XIV e XV. Brasília: Hinterlândia, 2009; DUARTE, Luís Miguel - "«Tomar O Pão Dos Coitados». Para Repensar a Crise do Século XIV em Portugal”. in COSTA, Leonor Freire, DUARTE, Luís Miguel e GARRIDO, Álvaro (ed.) - Economia, Instituições e Império: Estudos em Homenagem a Joaquim Romero Magalhães. Lisboa: Almedina, 2012, pp. 241-61; MIRANDA, Flávio - Portugal and the medieval Atlantic: commercial diplomacy, merchants, and trade, 1143-1488. Porto: Dissertação de doutoramento em História apresentada à Faculdade de Letras da Universidade do Porto, 2012; MUHAJ, Adrian - Quando todos os caminhos levavam a Portugal: Impacto da Guerra dos Cem anos na vida económica e política de Portugal (Séculos XIV-XV). Lisboa: Dissertação de Doutoramento em Letras, especialidade em História Medieval, apresentada à Faculdade de Letras da Universidade de Lisboa, 2013. Estudos de épocas posteriores podem representar uma importante base de apoio para os trabalhos de história económica medieval portuguesa, como por exemplo: BARROS, Amândio - Porto: a construção de um espaço marítimo nos alvores dos tempos modernos. Porto: Dissertação de doutoramento em História apresentada à Faculdade de Letras da Universidade do Porto, 2004; POLÓNIA, Amélia - $A$ Expansão Ultramarina Numa Perspectiva Local: O Porto de Vila do Conde no Séc. XVI. 2 vols. Lisboa: Imprensa Nacional - Casa da Moeda, 2007.

Medievalista online № 18| Julho - Dezembro 2015 ๑ IEM - Instituto de Estudos Medievais 4 www2.fcsh.unl.pt/iem/medievalista 
indica que historiadores anglo-saxónicos avançaram com a tese de "comercialização", com objetivo de contrariar a ideia enraizada na historiografia europeia sobre um campo estagnado, fechado sobre si mesmo e produzindo essencialmente para a sua autossubsistência. Esta teoria demonstra que o comércio «irrigou profundamente a sociedade e a vida rural: nenhum camponês, nas ilhas britânicas, estava a mais de $7 \mathrm{~km}$ de um mercado semanal, diz um deles; as feiras multiplicaram-se, estando ainda por averiguar, caso a caso, até que ponto elas faziam a ligação a tráfegos regionais ou mesmo internacionais». Esta visão releva o papel que alguns camponeses ricos podem ter desempenhado na economia rural desses séculos. Para além disso, enfatiza a necessidade de se rever «toda a vida e o trabalho no campo pensando que os camponeses de vários estratos e condições podiam revender, nos mercados ou nas feiras, os seus excedentes - logo podiam produzir para os mercados, que os senhores podiam aí comercializar tudo aquilo que recebessem de foros e rendas que fosse para além do que consumiam, e podiam também escolher culturas mais lucrativas. A circulação do dinheiro e do crédito nos campos reveste-se por isso de características muito complexas» ${ }^{8}$.

No caso de Espanha, particularmente interessante para a historiografia portuguesa, novas conceções historiográficas já vêm sido experimentadas nos últimos anos, com as investigações pioneiras de Julio Valdeón, cujo trabalho atestou a existência de quadros regionais não coincidentes com a visão tradicional da crise ${ }^{9}$. Nesta linha situa-se, também, o trabalho de Ermelindo Portela, sobre o bispado de Tui ${ }^{10}$. Mais recentemente, os trabalhos de Paulino Iradiel Murugarren ${ }^{11}$, Mercedes Borrero Fernández ${ }^{12}$, Hipólito

\footnotetext{
${ }^{8}$ DUARTE, Luís Miguel - “《Tomar O Pão Dos Coitados»”..., p. 242.

9 VALDEÓN BARUQUE, Julio - "La Crisis del siglo XIV en Castilla: Revisión del problema". in Revista de la Universidad de Madrid. 20 (1972), p. 161-82; VALDEÓN BARUQUE, Julio "Reflexiones Sobre La Crisis Bajomedieval En Castilla". in En La España Medieval. 2 (1984), pp. 10471060 .

${ }^{10}$ PORTELA SILVA, Ermelindo - La región del obispado de Tuy en los siglos XII al XV. Una sociedad en la expansión y en la crisis. Santiago de Compostela: Diputación Provincial de Pontevedra, 1976.

${ }^{11}$ IRADIEL MURUGARREN, Paulino - "La crisis Bajomedieval, un tiempo de conflictos". in IGLESIA DUARTE, J. I. de la (ed.) - XIV Semana de Estudios Medievales de Nájera: Conflictos Sociales, Políticos e Intelectuales en la España de los Siglos XIV y XV. Logroño: Gobierno de la Rioja, Instituto de Estudios Riojanos, 2004, pp. 13-48.
}

Medievalista online $N^{\circ} 18 \mid$ Julho - Dezembro 2015 ๑ IEM - Instituto de Estudos Medievais 5 www2.fcsh.unl.pt/iem/medievalista 
Rafael Oliva Herrer ${ }^{13}$, David Igual Luis ${ }^{14}$ e de Hilario Casado Alonso abrem um conjunto de perspetivas inovadoras no campo da economia medieval ibérica, as quais devem ser testadas, caso a caso, na historiografia portuguesa. Este último autor, Hilario Casado Alonso, num trabalho sobre a catedral de Burgos, constatou mesmo que no século XIV os cónegos deste cabido não sentiram a crise evidenciada pela historiografia europeia $^{15}$.

Em jeito de síntese, Luís Miguel Duarte nota que, com base na produção historiográfica estrangeira, «interessaria elaborar questionários novos e exaustivos: sobre a população, os seus números, a evolução, a distribuição, as tendências; sobre as lógicas de povoamento; sobre a organização produtiva dos campos, os sistemas de propriedade e de exploração, os tipos de cultivo, a penetração e o funcionamento do crédito e da moeda, a comercialização nos meios rurais $(. .)^{16}$; sobre a influência do reforço do aparelho de estado, da construção de um sistema fiscal central, da multiplicação de instâncias governativas, administrativas, judiciais, de instituições de regulação, no ordenamento e controle de relações económicas, sociais, financeiras; sobre os

12 BORRERO FERNÁNDEZ, Mercedes - "El mundo rural y la crisis del siglo XIV. Un tema historiográfico en proceso de revisión”. in Edad Media. Revista de Historia. Valladolid. 8 (2007), pp. 3758 .

${ }^{13}$ OLIVA HERRER, Hipólito Rafael - "El mundo rural en la corona De Castilla en la Baja Edad Media: Dinamicas socioeconomicas y nuevas perspectivas de analisis". in Edad Media. Revista de Historia. Valladolid. 8 (2007), pp. 295-328; OLIVA HERRER, Hipólito Rafael - "Reacciones a la crisis de 1504 en el mundo rural castellano". in OLIVA HERRER, Hipólito Rafael e BENITO I MONCLÚS, Pero (eds.) - Crisis de Subsistencia y Crisis Agrarias en la Edad Media. Sevilha: Universidad de Sevilla, 2007, pp. 259-76.

${ }^{14}$ IGUAL LUIS, David - “¿Crisis? ¿Qué crisis? El comercio internacional en los renos hispánicos en la Baja Edad Media”. in Edad Media. Revista de Historia. Valladolid. 8 (2007), pp. 203-23.

15 CASADO ALONSO, Hilario - "Existió la crisis del siglo XIV? Consideraciones a partir de los datos de la contabilidad de la catedral de Burgos". in VAL VALDIVIESO, María Isabel del e MARTÍNEZ SOPENA, Pascual (coord.) - Castilla y el Mundo Feudal. Homenaje al Professor Julio Valdeón. Vol. III. Valladolid: Junta de Castilla y León - Univeersidad de Valladolid, 2009, pp. 9-25.

${ }^{16}$ Veja-se a obra sobre o Baixo Mondego nos finais da Idade Média, de Maria Helena da Cruz Coelho, a qual, inclusive, antecipou, entre nós, em 1983, alguns dos temas que grassam atualmente pela historiografia internacional. Adicionalmente veja-se também: CASADO, Hilario - Señores, Mercaderes y Campesinos. La Comarca de Burgos en la Baja Edad Media. Valladolid: Junta de Castilla y León. Consejería de Cultura y Bienestar Social, 1987.

Medievalista online № 18| Julho - Dezembro 2015 ๑ IEM - Instituto de Estudos Medievais 6 www2.fcsh.unl.pt/iem/medievalista 
problemas do cereal, definindo claramente o que são crises agrárias, o que são carestias, o que são dificuldades de abastecimento, o que são fomes» ${ }^{17}$.

Esta pequena introdução indica de forma clara os objetivos deste artigo. Partindo de um contexto de guerra, entre 1369 e 1400, procuro lançar pistas e introduzir algumas questões sobre a produção e o comércio agrícolas, enquanto intento articular estes dois temas com algumas das perspetivas que observámos ao longo desta contextualização historiográfica. Note-se, no entanto, que a análise empreendida neste trabalho focar-se-á numa perspetiva global e não regional: procuro perceber a forma como a guerra influenciou a produção e o comércio agrícolas, ao mesmo tempo que analiso algumas das respostas dadas pela Coroa para corrigir estas dificuldades. Em suma, este texto representa uma porta aberta para futuras investigações.

\section{As marcas da guerra entre $1369-1400$}

Recrutar, produzir, abastecer: são três palavras-chave que moldam a narrativa deste texto. Embora se tenha cumprido apenas cerca de 30 anos entre 1369 e 1400, poder-se-á imaginar as dificuldades e desassossegos vividos pelas gentes do reino. Nestes tempos encontramos duas décadas marcadas por guerras, responsáveis pela abertura de feridas um pouco por todo o território ${ }^{18}$. Como tal, neste primeiro momento da exposição devem ser salientadas as consequências mais visíveis que seguiam no encalço da guerra, tendo sempre como horizonte de análise o facto de que, na Idade Média, os nãocombatentes (onde tinham especial relevo os lavradores), em conjunto com os seus bens

\footnotetext{
${ }^{17}$ DUARTE, Luís Miguel - “«Tomar O Pão Dos Coitados»”..., p. 247.

18 Sobre este assunto, cf.: "As Cicatrizes da Guerra no Espaço Fronteiriço Português (1250-1450)”, título sugestivo de um recente trabalho de João Gouveia Monteiro e de Miguel Gomes Martins, publicado em 2010, o qual nos oferece um retrato fiel sobre as peugadas deixadas pela guerra, em Portugal, durante a Idade Média.
} 
e propriedades, constituíam um objetivo militar de extrema importância estratégica e que convinha, a todo o custo, anular ${ }^{19}$.

A destruição de casas de morada representa uma face percetível deste flagelo. Neste contexto, deve ser nomeada a ação dos exércitos inimigos, como foi, por exemplo, aquilo que aconteceu durante o cerco de Lisboa, em 1384, movido pelas tropas de Juan I de Castela, no contexto do Período de Interregno português (1383-1385). Se recuarmos alguns anos, entre 1381 e 1382, observamos relatos sobre os estragos provocados por tropas aliadas da Coroa portuguesa, nomeadamente os exércitos mercenários ingleses, que se encontravam estacionadas no Vimieiro. No entanto, em caso de necessidade, não é surpreendente assistir-se a uma política de autodestruição. A título exemplificativo, existem registos sobre a utilização de muitas pedras de habitações lisboetas, em 1373 , na reconstrução da muralha fernandina ${ }^{20}$.

No espectro da destruição das casas de habitação própria associava-se frequentemente a devastação de terras cultiváveis ${ }^{21}$, não só pela ação direta da guerra, mas também pelo abandono dos campos agrícolas, quer devido ao recrutamento militar que recaía sobre os seus trabalhadores, quer porque estes padeciam às mãos dos exércitos inimigos, quer porque simplesmente fugiam para locais mais seguros.

Entre 1369 e 1400 multiplicam-se os documentos escritos que relatam estes problemas. Em 1370, a abadessa do mosteiro do Lorvão, situado no termo de Coimbra, intervém junto de D. Fernando, argumentando que o mosteiro possuía algumas marinhas de sal através das quais havia «prol e mantijmento». No entanto, nestes tempos de guerra, o mosteiro não podia aproveitar as suas marinhas porque os homens «que desto sabem»

19 MARTINS, Miguel Gomes - A Arte da Guerra em Portugal (1245-1367). Coimbra: Imprensa da Universidade de Coimbra, 2014.

${ }^{20}$ MONTEIRO, João Gouveia - “As feridas da guerra entre 1350 e 1450”. in MARTINS, Miguel Gomes e MONTEIRO, João Gouveia - As cicatrizes da guerra no espaço fronteiriço Português (1250-1450). Coimbra: Palimage, 2010, pp. 73-75. Para o período entre 1250 e 1350 veja-se MARTINS, Miguel Gomes - "A marca da guerra entre 1250 e 1350". in MARTINS, Miguel Gomes e MONTEIRO, João Gouveia - As cicatrizes da guerra no espaço fronteiriço Português (1250-1450). Coimbra: Palimage, 2010, pp. 35-37.

${ }^{21}$ MONTEIRO, João Gouveia - “As feridas da guerra entre 1350 e 1450”..., pp. 75-79; MARTINS, Miguel Gomes - “A marca da guerra entre 1250 e 1350”..., pp. 37-40.

Medievalista online $N^{\circ} 18 \mid$ Julho - Dezembro 2015 ๑ IEM - Instituto de Estudos Medievais 8 www2.fcsh.unl.pt/iem/medievalista 
são recrutados para «hir a frontaria serujr» ${ }^{22}$. Mais tarde, em 1372, reunidas as Cortes em Lisboa, logo no primeiro artigo dos Capítulos Gerais do Povo, ganham voz as queixas dos populares contra a guerra entre Portugal e Castela, a qual, em conjunto com as desvalorizações constantes da moeda, provocava «dapno aa nossa terra» ${ }^{23}$. No $22 .^{\circ}$ artigo destas Cortes este assunto é retomado. Diz o povo que o recrutamento de lavradores e de caseiros para servirem nas hostes régias provoca graves danos nas terras cultiváveis, pois estas ficam «despobradas e dapnificadas E que o nosso Reyno he porem peor manteudo» ${ }^{24}$.

Neste ano voltam a reunir-se Cortes, desta feita na cidade do Porto. As queixas dos populares, incorporadas logo no primeiro artigo dos Capítulos Gerais, são muito esclarecedoras sobre as dificuldades vividas pelas gentes do reino. O povo queixa-se que a guerra era responsável por «grande dano e carestia na nosa terra por mujtas Razoes que seeria longo de contar no que se o nosso poboo tijnha por mujto Agrauado (...) E porque o dano que da guerra avijnha nom se podia Bem enmendar s[em] Avendo paz» $^{25}$.

Com a chegada do Período de Interregno de 1383-85 sobrevieram novos enfrentamentos militares, colocando o reino a ferro e fogo. Em 1385, segundo Fernão Lopes, um contingente militar castelhano, comandado pelo arcebispo de Toledo, D. Pedro Tenório, invadiu Portugal utilizando a conhecida "estrada da Beira", destruindo tudo aquilo que encontrava, «a tallar as vinhas e paaes $(\ldots)\rangle^{26}$. Esta invasão prolongou-se até Viseu e reuniu um enorme saque; «contudo, a coluna castelhana acabou por se despedaçar já no regresso, ao ser dizimada por um pequeno exército português que a esperava na veiga de Trancoso» ${ }^{27}$. Mais tarde, em 1386, Gonçalo Aranha, cavaleiro e vassalo do rei, queixava-se que o seu couto de Cerzedelo tinha sido agravado. Este homem possuía a

\footnotetext{
${ }^{22}$ IAN/TT, Chancelaria de D. Fernando, Livro 1, fls. 67v. ${ }^{\circ}-68$.

${ }^{23}$ Cortes Portuguesas: Reinado de D. Fernando I (1367-1383). Ed. de A. H. de Oliveira Marques. Lisboa: Instituto Nacional de Investigação Científica, 1990, p. 16, vol. I, art. ${ }^{\circ} 1$. $^{\circ}$.

${ }^{24}$ Cortes Portuguesas: Reinado de D. Fernando I (1367-1383)..., p. 25, vol. I, art. ${ }^{\circ} 22 .{ }^{\circ}$.

${ }^{25}$ Cortes Portuguesas: Reinado de D. Fernando I (1367-1383) ..., p. 82, vol. I, art. ${ }^{\circ} 1 .{ }^{\circ}$.

${ }^{26}$ LOPES, Fernão - Cronica del rei Dom Joham I. Lisboa: INCM - Imprensa Nacional Casa da Moeda, 1997, p. 37, cap. XIX.

${ }^{27}$ MONTEIRO, João Gouveia - “As feridas da guerra entre 1350 e 1450”..., pp. 75-76, nt. 187.
}

Medievalista online $N^{\circ} 18 \mid$ Julho - Dezembro 2015 ๑ IEM - Instituto de Estudos Medievais 9 www2.fcsh.unl.pt/iem/medievalista 
jurisdição cível e criminal do dito lugar. No entanto, durante a guerra com Castela, Fernão Gomes da Silva, partidário do rei castelhano, que tinha em sua posse o castelo de Lanhoso, usurpou-lhe a jurisdição do couto de Cerzedelo, para além de derrubar os seus Paços, e obrigou os lavradores e caseiros da localidade a velar e roldar o referido castelo, incumbências a que estes homens estavam escusados ${ }^{28}$.

Um ano depois, em 1387, Estêvão Fernandes, abade de Bouças, provedor e administrador do morgado de Mindelo, lamenta-se a D. João I sobre o despovoamento que grassava por um conjunto de herdades da sua jurisdição ${ }^{29}$. Ouçamos o discurso do documento, bem mais esclarecedor do que qualquer linha que possa esboçar sobre o assunto: antes da guerra com Castela, segundo o clérigo, as terras tinham alguns caseiros que «aprouetauam [sic] os beens dellas per que se o dicto moorgado mantjnha assy no temporal como no spiritual».

No entanto, com os conflitos advieram as dificuldades, ao ponto de as herdades, quintãs e casais terem sido totalmente «danjficadas stroidas e delapidadas e <outrosy $>$ falidas dos caseyros per cazo da dicta guerra ${ }^{30}$. Assim, quando a guerra entrava pelas suas moradas, multiplicam-se os casos de homens que sofriam na pele várias dificuldades provocadas pelos conflitos bélicos. Num documento de 1390, D. João I reconhece que os moradores da Almendra de Riba Côa enfrentavam múltiplas vicissitudes, porque estes «servujrom muy bem em esta guerra $<$ e afanaram $>$ e padecerom mujto por nosso servjço»» ${ }^{31}$.

Igualmente adversa terá sido a destruição de instrumentos de produção agrícola ${ }^{32}$. O prejuízo que daqui advinha poderia levar, em alguns casos, meses ou anos a recuperar ${ }^{33}$. Em 1381, uma frota da Biscaia, composta por 87 velas, ao serviço de Juan I de Castela, provocou o caos numa quinta de Santa Iria de Azóia (Loures). Os homens que nela

\footnotetext{
${ }^{28}$ Chancelarias Portuguesas: D. João I. Ed. João José Alves Dias. Vol. I, t. 3. Lisboa: Centro de Estudos Históricos - Universidade Nova de Lisboa, 2004, doc. 1272, pp. 172-173.

${ }^{29}$ A saber: quintã de Alcadaria, Baraçal, Randide, quintã de Valverde e Vialonga.

${ }^{30}$ Chancelarias Portuguesas: D. João I, ed. cit., vol. II, t. 3, doc. 1443, pp. 207-208.

${ }^{31}$ Chancelarias Portuguesas: D. João I, ed. cit., vol. II, t. 1, doc. 438, p. 232.

${ }^{32}$ MONTEIRO, João Gouveia - “As feridas da guerra entre 1350 e $1450 ” . . .$, pp. 76-77.

${ }^{33}$ GOMES, Rita Costa - D. Fernando. Mem Martins: Círculo de Leitores, 2005, p. 111.
} 
viajavam, depois de desembarcar, incendiaram o Paço dos Arcos, bem como outros edifícios de menores dimensões, e destruíram cinco lagares de vinho, derrubando as suas portas, paredes e telhados. A índole assoladora desta força militar não terminaria sem antes devastarem as prensas dos lagares de azeite e de vinho, arruinarem o pombal, os alpendres, os pardieiros, os portais e os utensílios das adegas ${ }^{34}$.

A perda de gados, sobretudo nas zonas fronteiriças, era também objeto de grandes dificuldades para as gentes do reino ${ }^{35}$. Ao contrário daquilo que venho fazendo até aqui, não falarei sobre nenhum acontecimento vivenciado em Portugal. Foquemo-nos, antes, na célebre cavalgada de Antão Vasques por terras castelhanas. O guerreiro português, em outubro de 1385, não conseguiu reunir atempadamente, no Alentejo, com as forças de Nuno Álvares Pereira, as quais combateram os exércitos castelhanos nas margens do Guadiana. No entanto, Antão Vasques aproveitou a hoste militar que reuniu (400 homens de pé, 15 homens de armas, 20 besteiros e 40 batedores de cavalo) e comandoua desde Serpa para uma incursão em terras castelhanas, travando aí algumas escaramuças. Segundo Fernão Lopes, no rescaldo da cavalgada, os homens liderados por Antão Vasques apuraram um saque de 5.000 ovelhas, 4.000 vacas e 1.000 porcos, aos quais se juntavam ainda 10 cativos castelhanos ${ }^{36}$. Miguel Gomes Martins e João Gouveia Monteiro, em estudos recentes, atentaram que os prisioneiros de guerra podiam ser utilizados em trabalhos agrícolas enquanto servos, suprindo assim a ausência de mão-de-obra. No entanto, é difícil quantificar e qualificar a sua utilização, em Portugal, durante a Idade Média ${ }^{37}$. Encerrado este pequeno parêntesis, é altura de regressar à narrativa de Fernão Lopes. O cronista, a propósito da cavalgada empreendida pelos guerreiros de Antão Vasques, indica que entre os cativos encontrava-se um tal de Ascenço Martins, um lavrador rico de Aroche, que teve de pagar um resgate por si de

\footnotetext{
${ }^{34}$ MARQUES, José - “Devastações biscainhas na quinta da Azóia (1381)”. in Revista Portuguesa de História. Vol. XXXI, n. ${ }^{\circ} 2$ (1996), pp. 214-216.

${ }^{35}$ MONTEIRO, João Gouveia - “As feridas da guerra entre 1350 e 1450”..., pp. 77-78.

${ }^{36}$ LOPES, Fernão - Cronica del rei Dom Joham I..., caps. LIX e LX, pp. 144-149.

${ }^{37}$ Comunicações proferidas sobre os temas «Prisoners of War in Portugal, 1128-1350» e «Prisoners of War in Portugal, 1350-1450», respetivamente, no âmbito do congresso «Common Men and Women at War, 300-1500 AD», entre 4 e 6 de Junho de 2014, Trondheim (Noruega). Prevê-se que as atas do congresso sejam publicadas em finais de 2015, inícios de 2016.
}

Medievalista online № 18| Julho - Dezembro 2015 ๑ IEM - Instituto de Estudos Medievais 11 www2.fcsh.unl.pt/iem/medievalista 
100.000 reais $^{38}$ : trata-se, portanto, de números verdadeiramente astronómicos! Mesmo que o cronista possa ter carregado no acelerador para empolar o sucesso deste assalto, lembremos estes dados, pois, ainda que exagerados, demonstram que em tempos de guerra (e de crise, em geral), existiam homens a ganhar muito dinheiro.

Para contornar os problemas que aqui descrevi, a Monarquia procurou, desde cedo, afastar os lavradores das lides da guerra, para que estes se dedicassem em exclusivo a uma função fundamental para o abastecimento do reino. Assim, vemos o impedimento de se recrutar besteiros do conto junto deste grupo de homens, limitando-se o seu arrolamento ao corpo de mesteirais, preferencialmente sobre aqueles que não lavrassem continuadamente com uma junta de bois ${ }^{39}$. De outro modo, assiste-se à promulgação de sucessivas prerrogativas gerais para povoadores de lugares onde se sentia a escassez de gentes, tendo como objetivo incrementar a produção agrícola e melhorar a defesa militar das terras, tantas vezes localizadas em pontos raianos estratégicos. Assim aconteceu com alguns dos casos que citei anteriormente, sendo outorgadas cartas de privilégios para os pedidos da abadessa do mosteiro de Lorvão, em 1370, e do administrador do morgado de Mindelo, em 1387. Esclarecedora é também uma carta de privilégios concedida, em 1378, aos povoadores de Torres Novas. Segundo D. Fernando, a cerca da vila foi reconstruída recentemente, mas «os moradores della som muj poucos e conpre que busquemos razam como se mjlhor aia de pobrar». Assim, para corrigir a situação, o monarca concede vários privilégios, entre os quais convém destacar a isenção de serviço militar, a isenção de pagamento de fintas e talhas concelhias, bem como a dispensa de pagamento de almotaçaria no caso de venda de pescados, caças e outros víveres, respetivamente, pelos pescadores, caçadores e almotacés que povoassem o lugar ${ }^{40}$. Mais tarde, em 1383, Gonçalo Rodrigues Araújo recebia um préstamo de D. Fernando «em compensação por terras que tinham sido queimadas durante as Guerras Fernandinas com Castela» ${ }^{41}$. Os moradores de Évora, pelo apoio que prestaram à causa de D. João, Mestre de Avis, durante o Período de Interregno, foram agraciados, em 1385, com o

${ }^{38}$ LOPES, Fernão - Cronica del rei Dom Joham I..., caps. LIX e LX, pp. 144-149.

${ }^{39}$ Ordenações Afonsinas. Lisboa: Fundação Calouste Gulbenkian, 1984, vol. I, tít. LXIX, n. ${ }^{\circ}$ 29, p. 437.

${ }^{40}$ IAN/TT, Chancelaria de D. Fernando, Livro 2, fls. 26v. ${ }^{\circ}-27$.

${ }^{41}$ MONTEIRO, João Gouveia - “As feridas da guerra entre 1350 e $1450 ” . . .$, p. 75.

Medievalista online № 18| Julho - Dezembro 2015 ๑ IEM - Instituto de Estudos Medievais 12 www2.fcsh.unl.pt/iem/medievalista 
privilégio de isenção de pagamento de tributos na venda «em praça e $<\mathrm{em}>$ no terreiro .s. de pam cozido e trigo e mjlho e centeo e ceuada de que leuam huũ djnheiro do alqueyre $\gg^{42}$.

As múltiplas concessões de privilégios observáveis nas Chancelarias dos dois monarcas aqui estudados atestam as dificuldades e a desordem que a guerra trouxe à produção agrícola do reino e aos seus trabalhadores. Assim, à devastação e à deserção dos campos agrícolas - não raras vezes como consequência de ambas - poderia juntar-se a desorganização da vida profissional ${ }^{43}$. Aquando da Primeira Guerra Fernandina, nos meses de agosto e setembro de 1369, os exércitos do rei castelhano, Enrique II, tomaram com relativa facilidade as praças portuguesas de Bragança, Vinhais e Outeiro de Miranda ${ }^{44}$. Segundo Fernão Lopes, isto sucedeu porque as gentes de Trás-os-Montes andavam fugidas pelos montes por causa dos temores provocados pela guerra ${ }^{45}$. Um caso mais específico surge na Chancelaria de D. João I. Em 1385, o monarca trata de regulamentar certos problemas que tinham surgido em Santarém durante os conflitos com Castela. Nesta localidade alguns lavradores, bem como «outros homens que som da lauoira», organizaram-se como um bando guerreiro durante a guerra. Quando a paz regressou ao concelho estes homens continuavam a pilhar, a roubar e a matar e recusavam voltar às suas lavouras. Alertado para este problema, D. João I acata o pedido dos homens-bons do município, o qual consistia num ultimato movido aos lavradores para que estes regressassem às suas antigas tarefas, ameaçando-os com a pena de morte ${ }^{46}$.

No encalço da guerra surgiam frequentemente problemas relacionados com $\mathrm{o}$ abastecimento de cidades do reino. $\mathrm{O}$ caso mais flagrante seria o de Lisboa. Existem relatos, em 1372, sobre a diminuição do número de vendedores de carne e de pão na

\footnotetext{
${ }^{42} \mathrm{O}$ monarca exclui do âmbito deste privilégio, como é evidente, aqueles que não eram da cidade mas que lá vendiam estes produtos (Chancelarias Portuguesas. D. João I, ed. cit., vol. I, t. 2, doc. 825, p. 162).

${ }^{43}$ Sobre este assunto veja-se MONTEIRO, João Gouveia - "As feridas da guerra entre 1350 e 1450 "..., pp. 91-95 e MARTINS, Miguel Gomes - “A marca da guerra entre 1250 e 1350”..., pp. 48-52.

${ }^{44}$ MONTEIRO, João Gouveia - “As feridas da guerra entre 1350 e $1450 ” . . .$, p. 85.

${ }^{45}$ LOPES, Fernão - Cronica del rei Dom Joham I..., cap. XXXV, p. 115-117.

${ }^{46}$ Chancelarias Portuguesas: D. João, ed. cit., vol. I, t. 2, doc. 666, p. 77.
} 
cidade, denotando-se um sinal claro da falta desses produtos nos locais de venda. Um ano depois, em 1373, as hostes militares de Enrique II de Castela devastaram, principalmente através do fogo, múltiplos campos de cultivo e explorações agrícolas e pecuárias quer da cidade, quer do seu termo. Estas incursões castelhanas afetaram gravemente o abastecimento de Lisboa, sobretudo porque a guerra diminuiu substancialmente a produção das zonas mais próximas da capital. Em 1374 esta situação é relevada pelos procuradores da cidade. Estes lamentam-se a D. Fernando sobre a falta de carne, de pão e de outros géneros alimentares nos mercados lisboetas. O monarca responde autorizando, sem impor qualquer tipo de restrições, a "livre-saca" de mantimentos com destino à capital do reino ${ }^{47}$.

Os problemas relacionados com o abastecimento de Lisboa persistiram após a morte de D. Fernando, intensificando-se quando a capital esteve sitiada pelas forças castelhanas, em 1384. No entanto, Lisboa não terá conhecido um ponto de rutura provocado pela escassez de víveres, pois esta não atingiu o momento que levava à necessidade de rendição, para evitar que a cidade fosse totalmente sucumbida pela fome. Para tal, deverá ter contribuído a expulsão do interior das muralhas, por duas ou três vezes, a mando do Mestre de Avis, das gentes que não tivessem alimentos, nem que pudessem auxiliar nas tarefas de defesa de Lisboa.

As dificuldades de abastecimento de uma cidade cercada resultavam, essencialmente, de uma estratégia de ataques organizados aos circuitos normais de provimento. Assim, em 1384, as forças militares de Juan I lançavam ofensivas a partir de pontos estratégicos em seu poder, a saber: Santarém, Sintra, Torres Vedras, Alenquer e Óbidos; a estes raides juntava-se o bloqueio naval do rio Tejo ${ }^{48}$.

Com estes exemplos é possível perceber que quando a guerra trilhava o seu curso pelo reino sobrevinham, então, as dificuldades de abastecimento, situação que se agudizava

\footnotetext{
${ }^{47}$ MARTINS, Miguel Gomes - "Abastecer as cidades em contexto de guerra: o cerco de Lisboa de 1384". in ARÍZAGA BOLUMBURU, Beatriz e ÁNGEL SOLÓRZANO, Beatriz (Coords.) - Alimentar la ciudad en la Edad Media. Logroño: Instituto de Estudios Riojanos, 2009, pp. 133-135.

${ }^{48}$ MARTINS, Miguel Gomes - Lisboa e a Guerra (1367-1411). Lisboa: Livros Horizonte, 2001, pp. 111112.
} 
no maior centro urbano português. Aliás, a «dependência da capital relativamente a todos estes víveres assentava assim num equilíbrio delicado, imediatamente afectado quando ocorria qualquer interrupção ou perturbação ao seu transporte e comércio ou sempre que se verificava uma quebra mais acentuada da produção agrícola e pecuária nos centros fornecedores, como acontecia em períodos de guerra». Isto é, «quando as estradas eram inseguras e poucos corriam o risco de as percorrer, quando as culturas eram incendiadas, os mantimentos confiscados, pilhados e destruídos; quando o gado era morto ou roubado; e quando a mão-de-obra agrícola abandonava os campos em busca da segurança - muitas vezes ilusória - conferida pelas muralhas das vilas e cidades ${ }^{49}$.

A guerra naval contribuía também para a criação de problemas de abastecimento nas cidades, quer através de práticas de pirataria ou de corso $^{50}$, quer por meio de bloqueios navais, conforme vimos no parágrafo anterior, quer pelo recorrente desvio de navios mercantes para a guerra, podendo levar, em alguns casos, à sua captura ou destruição ${ }^{51}$. Em tempos de guerra, empresa particularmente corajosa era a dos homens que se lançavam ao mar para comerciar, arriscando a possibilidade de encontrar armadas inimigas $^{52}$, ou outro tipo de "malfeitores", tal como descreve um documento muito interessante, datado de 1404. Luís Martins, mercador de Lisboa, recebe, neste ano, uma carta de quitação de D. João I. Neste documento, é indicado que este homem conheceu a ruína financeira. $\mathrm{Na}$ data da feitura do documento passavam-se dois anos desde que alguns rendeiros, entre os quais se incluía este homem, faltaram ao pagamento de muitas das suas rendas, as quais perfaziam somas monetárias muito significativas. De

\footnotetext{
${ }^{49}$ MARTINS, Miguel Gomes - "Abastecer as cidades em contexto de guerra: o cerco de Lisboa de 1384 "..., p. 136.

${ }^{50}$ Veja-se, por exemplo, BARATA, Filipe Themudo - Navegação, Comércio e Relações Políticas: os Portugueses no Mediterrâneo Ocidental (1385-1466). Lisboa: Fundação Calouste Gulbenkian, 1998; BARROS, Amândio - "O Porto contra os corsários. (A expedição de 1469)", in Revista da Faculdade de Letras. História. Porto. Vol. III, $\mathrm{n}^{\circ} .1$ (2000), p. 11-27; BARROS, Amândio - Porto: a construção de um espaço marítimo nos alvores dos tempos modernos. Porto: Dissertação de doutoramento em História apresentada à Faculdade de Letras da Universidade do Porto, 2004.

${ }_{51}$ Veja-se: DUARTE, Luís Miguel - "A Marinha de Guerra. A Pólvora. O Norte de África". in BARATA, Manuel Themudo e TEIXEIRA, Nuno Severiano (dir.) - Nova História Militar de Portugal. vol. I. Rio de Mouro: Círculo de Leitores, 2004, pp. 290-442.

${ }^{52}$ MARTINS, Miguel Gomes - Lisboa e a Guerra (1367-1411)..., p. 114.
}

Medievalista online № 18| Julho - Dezembro 2015 ๑ IEM - Instituto de Estudos Medievais 15 www2.fcsh.unl.pt/iem/medievalista 
tal forma que foram penhorados bens móveis e de raiz a Luís Martins - avaliados em 150.000 reais! -, após ter sido preso, os quais foram rematados a Luís Nicolau, ourives em Lisboa. Apesar do dinheiro arrecadado, aparentemente esta soma muito significativa não era suficiente para saldar a totalidade das dívidas, uma vez que o monarca decidiu outorgar uma quitação pelos valores monetários que este mercador ainda devia, perdoando-lhe também pelo seu incumprimento. Mas que causas eram estas que levaram um homem, aparentemente bem abonado, à ruína financeira? O documento é esclarecedor na resposta a esta questão: «E como asy foi grande per dalgũus cassos fortoytos que no dito tempo acontecerom conuem a saber tormentas desfeitas e Jntes (sic) malfeitores que andauom pollo mar E outrosy começos e bollimentos dee guerra que se entõ Segiam e carestija de pam por a quall rrazõ se perderom mujtos naujos asy dos nossos regnos como doutros estrangeiros que vinham para a dita Çidade e Outrosy partirom della com entençõ de tornar hir com seus empregos E esso medes outros naujos e mercadores que no dito tempo leixharom de carregar e segir sua viagem pera a dita Çidade com Reçeo e themor dos ditos malfeitores $[\ldots] \gg{ }^{53}$.

Os abusos de poderosos e dos exércitos provocavam também graves dificuldades às gentes do reino, sobretudo através de excessos no direito de aposentadoria. Os abusos dos combatentes eram perpetrados nas populações dos lugares por onde estes marchavam, quer pela sua necessidade de alimentação, quer pelo referido privilégio de aposentadoria. Deve ser salientado que o abastecimento dos guerreiros era feito, geralmente, pela apropriação de víveres aos produtores agrícolas, sem que estes fossem, na maioria das vezes, ressarcidos pelas suas perdas. Nestas circunstâncias, a passagem de um exército por um determinado lugar, fosse hostil ou não, acarretava sempre preocupações acrescidas para a Monarquia, para a respetiva comarca e para as suas populações $^{54}$. Ouçamos o que um documento da Chancelaria de D. João I nos tem a dizer sobre estes gravames. Em 1385, o abade do mosteiro de São João de Alpendorada

\footnotetext{
${ }^{53}$ Descobrimentos portugueses: documentos para a sua história. Ed. de João Martins da Silva Marques. Vol. I. Lisboa: Instituto Nacional de Investigação Científica, 1988, doc. 209, pp. 217-218.

${ }^{54}$ MONTEIRO, João Gouveia e SILVA, Vasco Jorge Rosa da - "A Vivência da Guerra no Outono da Idade Média”. in BARATA, Manuel Themudo e TEIXEIRA, Nuno Severiano (dir.) - Nova História Militar de Portugal. vol. I. Rio de Mouro: Círculo de Leitores, 2004, p. 15.
} 
leva à agenda de D. João I um problema relacionado com umas quintãs das quais o referido mosteiro recebe pensões, foros de pão, vinho, carnes e rendas estipendiárias. Para além disso, o abade argumenta que é com estas rendas e produtos que o mosteiro e a sua familia $^{55}$ se mantêm. No entanto, existem fidalgos e pessoas poderosas, aos quais o monarca deu as ditas terras, que pousam nas quintãs onde têm os referidos mantimentos. O clérigo argumenta que estes poderosos «lhes britam as portas das adegas e casas e lhes comem todo e leuam pera hu se pagam emquanto stam em as dictas terras $\mathrm{E}$ que os scudeiros dos dictos fidalgos e pioões se vaão pousar com os dictos seus lauradores e lhes tomam quanto ham assy os $<$ seus $>$ djreitos que os dictos lauradores ham de dar ao dicto dom abade e conuento $\mathrm{E}$ que os dictos seus lauradores teem suas molheres e filhos e que nom sabem se guardem suas casas se vaão laurar porque receam de receberem delles deshonrra por a qual razam os dictos dom abade e conuento e seus caseiros receberom e recebem grande perda e dampno per tal guisa que nom podem manteer suas casas porque padecem grande mjngoa e fome» ${ }^{56}$. Em síntese, estes lavradores, além de verem os seus mantimentos confiscados abusivamente, ainda tinham receio de lavrar as suas terras, abandonando assim as suas mulheres e filhos à mercê da índole opressora dos escudeiros e peões destes fidalgos. Se recuarmos até ao reinado de D. Fernando, observamos que estes excessos eram recorrentes em períodos de guerra. Reunidas as Cortes de Lisboa, em 1371, no 47. ${ }^{\circ}$ artigo dos Capítulos Gerais do Povo, os procuradores queixam-se que «quando taaes poderosos e sas companhas chegam pelos montes alheos tomam per força o que acham em elles e nas casas deles per que se os lauradores ham de manteer e lhjs dapnam e estragam o seu per tal guisa que os lauradores as desenparam ca lhjs couem E lhes he melhor de os desempararem ca de os manterem». Pediam, portanto, que fosse colocado «escarmento» em tais poderosos, para evitar que os lavradores abandonassem as lavouras «que som proueijtosas ao Reijno pera mantijmento do poboo E por esto leijxam de pousar nas

\footnotetext{
${ }^{55}$ A familia monástica é, em linhas gerais, um agrupamento complexo e numeroso, que reúne pessoas de todas as condições sociais, que ambicionam viver à sombra do mosteiro, sob a sua proteção. MATTOSO, José - O Monaquismo Ibérico e Cluny. Rio de Mouro: Círculo de Leitores, 2002.

${ }^{56}$ Chancelarias Portuguesa. D. João I, ed. cit., vol. I, t. 2, doc. 931, pp. 236-237.
}

Medievalista online № 18| Julho - Dezembro 2015 ๑ IEM - Instituto de Estudos Medievais 17 www2.fcsh.unl.pt/iem/medievalista 
vilas e uaão pousar nos montes» ${ }^{57}$. D. Fernando toma, claro está, o partido dos lavradores. No entanto, é muito difícil acreditar que estes homens tenham sido devidamente protegidos...

Apesar de a Monarquia procurar solucionar os gravames cometidos pelos poderosos, dificilmente estes se resolviam, até porque a própria Coroa se intrometia em negócios e agravava os produtores e comerciantes do reino. São sucessivas as queixas dos povos do reino sobre a apropriação de recursos e de bens por parte da Monarquia e dos seus oficiais, sem nunca ressarcirem os prejudicados ${ }^{58}$. D. Fernando procurou mesmo envolver-se no jogo das trocas, desejando assim ver os seus recursos exponenciados através de um envolvimento no comércio ${ }^{59}$, praticado por vezes fora das "normas"60. Esse é o caso descrito numa queixa muito dura dirigida ao rei pelos povos, feita nas Cortes de Lisboa de 1371. Trata-se de um documento complexo ${ }^{61}$. Por isso, fiquemos com a análise esclarecedora feita por Luís Miguel Duarte sobre o seu conteúdo: «Os reis anteriores - começam os povos, indicando que vêm aí duras acusações ao rei em exercício - recolhiam, dos próprios da Coroa muito pão; o suficiente para acudir ao povo quando o cereal faltava. Se tinham que recompensar um súbdito, recorriam ao seu tesouro. D. Fernando multiplicara as doações de terras e vilas; quando precisou de pão para a frota de guerra, não encontrou melhor solução do que "tomar o pam dos coitados" - por preços baixíssimos que, mesmo assim, em muitos casos ficaram por pagar. Parece mau, mas foi pior: nem todo o pão assim requisitado foi necessário para as galés; o que sobrou foi revendido pelos oficiais régios com lucros desmedidos, acontecendo que muitos dos "coitados" a quem ele fora tomado a cinco soldos, e não

${ }^{57}$ Cortes Portuguesas: Reinado de D. Fernando I (1367-1383)..., vol. I, p. 38, art. ${ }^{\circ} 47^{\circ}$.

${ }^{58}$ Cf., por exemplo, Cortes Portuguesas: Reinado de D. Fernando I (1367-1383)..., vol. I, art. ${ }^{\circ} 5^{\circ}$, pp. 126-127.

${ }^{59}$ GOMES, Rita Costa - D. Fernando..., p. 116.

${ }^{60}$ Isto verifica-se não só no comércio, mas também nos mecanismos que lhe estavam associados. Nos fretamentos marítimos lisboetas, empresa que fornecia lucros apetíceis, verifica-se uma intervenção direta de D. Fernando, estipulando que as barcas que se encontravam ao serviço da Coroa necessitariam de ser as primeiras a ser fretadas na localidade. As restantes apenas poderiam ser contratadas quando não houvesse barcas régias nos portos. Sobre este assunto veja-se um artigo da minha autoria, que se encontra em fase de publicação, com o título "De Lisboa rumo ao reino: Fretamentos e fretadores nos séculos XIV e XV".

${ }^{61}$ Cortes Portuguesas: Reinado de D. Fernando I (1367-1383)..., vol. I, art. ${ }^{\circ} 43^{\circ}$, p. 35. 
pago, se viram forçados a comprá-lo - o seu cereal - aos homens do rei por cinco libras. Descontando os exageros retóricos, a acusação é brutal: era uma desonra o rei enriquecer com a perda dos outros, "mormente por auto tam enlicito"» ${ }^{62}$.

\section{A especulação de preços de produtos agrícolas}

As práticas abusivas descritas no parágrafo anterior não encerram o género de excessos cometidos por gentes poderosas em tempos de guerras. A especulação de preços, muito característica de períodos de carestia agrícola ${ }^{63}$, encontra-se muito bem documentada, quer em Portugal, quer nos restantes reinos peninsulares ${ }^{64}$. Neste último caso, Oliva Ferrer atentou que, em Castela, é detetada uma certa tendência para que os senhores recebam os seus pagamentos em espécies, preferencialmente em cereal, para evitar a sua depreciação, enquanto propiciavam a uma aristocracia de clara vocação rentista um cenário privilegiado para conseguir lucrar muito com a especulação de preços nos mercados urbanos ${ }^{65}$. Nos momentos de crise de subsistência sobrevém um cenário privilegiado, no qual se revela a complexidade dos circuitos de abastecimento agrícolas, os múltiplos intermediários que a ele se encontram associados e os interesses distintos que se encontram implicados, capazes de beneficiar diversos estratos sociais, entre eles a elite das comunidades rurais ${ }^{66}$. Em Portugal, por sua vez, estes dados são

\footnotetext{
${ }^{62}$ DUARTE, Luís Miguel - “«Tomar O Pão Dos Coitados».”..., pp. 257-258.

${ }^{63}$ Cf. PALERMO, Luciano - Sviluppo Economico e Società Preindustriali. Cicli, Strutture e Congiunture in Europa dal Medioevo Alla Prima Età Moderna. Roma: Viella, 1997.

${ }^{64}$ Cf., por exemplo: SANTAMARÍA LANCHO, Miguel - "Del concejo y su término a la comunidad de ciudad y tierra: Surgimiento y transformación del señorío urbano de Segovia (siglos XIII-XVI)". Studia Historica. Historia Medieval. Salamanca. 2 (1985), pp. 103-105; BORRERO FERNÁNDEZ, Mercedes "El mundo rural y la crisis del siglo XIV. Un tema historiográfico en proceso de revisión"..., pp.53-62; CASADO, Hilario - Señores, Mercaderes y Campesinos. La Comarca de Burgos en la Baja Edad Media..., p. 501; OLIVA HERRER, Hipólito Rafael - "Reacciones a la crisis de 1504 en el mundo rural castellano". in OLIVA HERRER, Hipólito Rafael e BENITO I MONCLÚS, Pero (eds.) - Crisis de Subsistencia y Crisis Agrarias en la Edad Media. Sevilha: Universidad de Sevilla, 2007, pp. 259-276.

${ }^{65}$ OLIVA HERRER, Hipólito Rafael - "El mundo rural en la corona De Castilla en la Baja Edad Media: Dinamicas socioeconomicas y nuevas perspectivas de analisis"..., p. 322.

${ }^{66}$ OLIVA HERRER, Hipólito Rafael - "El mundo rural en la corona De Castilla en la Baja Edad Media: Dinamicas socioeconomicas y nuevas perspectivas de analisis"..., pp. 321-322.
}

Medievalista online № 18| Julho - Dezembro 2015 ๑ IEM - Instituto de Estudos Medievais 19 www2.fcsh.unl.pt/iem/medievalista 
corroborados. A subida dos preços acontecia frequentemente em períodos de guerra ${ }^{67}$, pois associa-se à intrínseca correlação entre a diminuição da oferta e o aumento da procura. Apesar de se tratar de uma situação bem conhecida pela historiografia portuguesa, considero que esta temática ainda não terá sido estudada com a devida profundidade. Habitualmente assume-se que, por exemplo, algumas posturas tomadas pelas autoridades dos concelhos e da Monarquia desejavam proibir o açambarcamento de trigo, quando, na minha opinião, estas pretendiam contrariar a existência de manobras especulativas. Deixemos, no entanto, que os documentos falem por si próprios. Nas Cortes de Lisboa de 1371, os povos queixam-se que muitos prelados, mestres e ricos-homens têm pelas comarcas do reino vários celeiros cheios de pão e de vinho. No entanto, compram e estragam os produtos de outros vendedores. Mais grave ainda, segundo os povos, estes homens poderosos queixam-se «muj mal» dos preços praticados pelos vendedores menos abonados, exigindo que estes vendam o pão e o vinho pelo valor estipulado pelas leis de almotaçaria. Ao ouvir este relato facilmente nos questionamos sobre os motivos que levavam estes poderosos a preservar armazéns de pão e vinho bem guarnecidos enquanto se alimentavam dos produtos dos vendedores mais pobres. A resposta é dada pelo próprio documento. Estes indivíduos não «querem uender ssenom em tempos que ueem grande carestija na terra», quando os preços estivessem inflacionados e, assim, providenciassem lucros mais apetecíveis. Em resposta a esta situação, D. Fernando ordena que os indivíduos, «em tempo çerto», se sirvam e vendam o pão e o vinho que possuírem, salvo se houver alguém que lhes queira vender estes produtos de livre vontade ${ }^{68}$. Como é evidente, estas ações facilmente levavam a um escoamento mais acentuado do pão disponível para venda nos mercados, fazendo, assim, com que os preços se inflacionassem por influência destes homens poderosos. Esta concorrência desleal era muitas vezes ampliada pelo recurso a elementos de autoridade de que estes indivíduos se investiam. Estes eram os casos dos prelados que referi, que se envolviam no negócio da regatia do pão, sem pagar sisas ${ }^{69}$,

\footnotetext{
${ }^{67}$ BOUTHOUL, Gaston - O Fenómeno Guerra. Lisboa: Estúdios Cor, 1966, p. 273.

${ }^{68}$ Cortes Portuguesas: Reinado de D. Fernando I (1367-1383)..., vol. I, art. ${ }^{\circ} 70^{\circ}$. p. 48.

69 Optei por não esboçar nenhum apontamento sobre a questão das sisas e da tributação, pois foi publicado recentemente, em 2014, um artigo muito esclarecedor sobre este assunto. Cf.: HENRIQUES,
}

Medievalista online № 18| Julho - Dezembro 2015 ๑ IEM - Instituto de Estudos Medievais 20 www2.fcsh.unl.pt/iem/medievalista 
enquanto procuravam penhorar bens alegando que eram homens privilegiados. Quando alguém se queixava «o bispo e sseus vigairos» tratavam de excomungar essa pessoa, «o que he muj sem rrazam (...)», argumentava o povo ${ }^{70}$. Os próprios regatões também se terão envolvido em práticas especulativas. Segundo o povo, muitos regatões «andam pelas terras que poem em elas grandes carestijas e ssom aazo de grandes dapnos». Pediam, portanto, que deixasse de haver regatões de pão, de gado e de bestas nos lugares. O monarca refere que, antes de receber este pedido, já havia tomado esta medida $^{71}$, concluindo-se, assim, que a diretiva régia anterior não teve qualquer efeito normativo nestas questões. Quais seriam, no entanto, os lucros destes homens poderosos? É muito difícil quantificar os ganhos provenientes da especulação, mas existem duas sugestões pertinentes feitas em Cortes. Os povos, nas Cortes do Porto de 1372, afirmam que os poderosos «estauam com grandes tesouros de pam e de vjnho» porque o tabelamento da almotaçaria não se aplicava senão aos pequenos, pois os grandes, diz o povo, tomavam as «cousas dos pequenos E Reuendiom nas dePojs por sete tanto que o que lhj custaua» ${ }^{72}$ : ou seja, lucros multiplicados por sete em cada alqueire de pão! Isto é, segundo outra queixa dos povos, muitas vezes o alqueire de trigo comprado por 5 soldos era depois revendido pelos poderosos ${ }^{73}$ por 5 libras $^{74}$ ! Estas práticas especulativas, em estreita articulação com os danos provocados pela guerra, chegavam ao ponto de fazer com que os territórios - e são os povos que o dizem fossem «mjnguados (...) de pam gaados e doutras cousas que am mester pera sseus mantijmentos» ${ }^{75}$.

As queixas dos povos indicam que em momentos delicados, como eram os de guerra, muitas das vezes, os produtores e comerciantes menos abonados e que não se investiam de nenhum tipo de autoridade, impotentes perante os cenários que se desenhavam,

António Castro - "The Rise of a Tax State: Portugal, 1371-1401". in E-journal of Portuguese History. Vol. 12, n. 1 (2014), pp. 49-66.

${ }^{70}$ Cortes Portuguesas: Reinado de D. Fernando I (1367-1383)..., vol. I, art. ${ }^{\circ} 44^{\circ}$, p. 36.

${ }^{71}$ Cortes Portuguesas: Reinado de D. Fernando I (1367-1383)..., vol. I, art. ${ }^{\circ} 65^{\circ}$, p. 46.

${ }^{72}$ Cortes Portuguesas: Reinado de D. Fernando I (1367-1383)..., vol. I, art. ${ }^{\circ} 3^{\circ}$, p. 84.

${ }^{73}$ No caso deste documento, analisado anteriormente, eram os próprios oficiais do rei que incorriam nestas práticas...

${ }^{74}$ Cortes Portuguesas: Reinado de D. Fernando I (1367-1383)..., vol. I, art. ${ }^{\circ} 43^{\circ}$, p. 35.

${ }^{75}$ Cortes Portuguesas: Reinado de D. Fernando I (1367-1383)..., vol. I, art. ${ }^{\circ}$ 65ํ․ p. 46. 
limitavam-se a acenar negativamente com a cabeça, resignados, face aos gravames cometidos pelos poderosos do reino. O cenário descrito pelos povos parece péssimo, mas deve ser relativizado: quem é este povo que formula estas duras queixas em Cortes? De acordo com Armindo de Sousa, apesar de os procuradores municipais afirmarem nas Cortes que «são os autênticos e devotados representantes dos povos do reino, tal afirmação não passa, objectivamente, de floreado retórico» ${ }^{76}$. Isto é, estes homens, na verdade, representavam a voz dos indivíduos que tinham poder decisório nas vereações concelhias, ou, numa perspetiva mais otimista, reproduziam os desejos de algumas dezenas de habitantes que possuíam relativa importância nos respetivos lugares. Portanto, é necessário assumir que as expressões dos procuradores concelhios que reclamam a "representativade universal" dos povos do reino devem ser encaradas como um mero instrumento de retórica política. Aliás, os grupos sociais representados pelos embaixadores municipais nem sempre se limitavam aos indivíduos pertencentes ao povo. Assim, vemos procuradores concelhios a argumentar em favor de fidalgos em

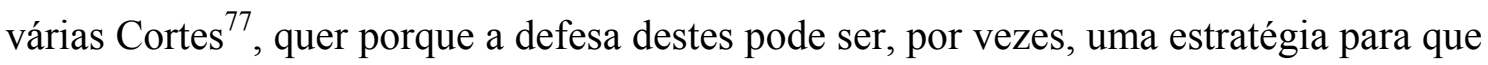
os povos consigam deferimentos, quer porque, em muitos lugares, os fidalgos e o povo associavam-se na governação municipal. Para além disso, os concelhos não rejeitavam a escolha para seus procuradores de homens de fidalgos e de clérigos. Em suma, prossegue Armindo de Sousa, «entre fidalgos e povo, especialmente entre os estratos mais baixos de um grupo e os mais elevados de outro, havia comunhão de interesses ou, ao menos, convivência amigável» ${ }^{78}$.

Ao longo desta última nota explicativa percebemos que o discurso dos povos, o qual acusava os poderosos do reino de cometer práticas especulativas que inflacionavam o preço dos víveres, necessita de ser relativizado. Esta dedução impele a formulação de uma nova questão: eram apenas os privilegiados que praticavam manobras especulativas

76 SOUSA, Armindo de - As Cortes Medievais Portuguesas. Vol. I. Porto: Instituto Nacional de Investigação Científica - Centro de História da Universidade do Porto, 1990, p. 205.

${ }^{77}$ Armindo de Sousa indica vários exemplos: Cortes de Elvas, de 1361; Cortes de Lisboa de 1371; Cortes de Guimarães de 1401; Cortes de Lisboa de 1427 e 1455; e, finalmente, Cortes de Évora de 1490. SOUSA, Armindo de - As Cortes Medievais Portuguesas..., vol. I, p. 206.

${ }^{78}$ SOUSA, Armindo de - As Cortes Medievais Portuguesas..., vol. I, pp. 189-214.

Medievalista online № 18| Julho - Dezembro 2015 @ IEM - Instituto de Estudos Medievais 22 www2.fcsh.unl.pt/iem/medievalista 
de preços nos mercados medievais? Alguns dos relatos citados anteriormente contêm dados interessantes que merecem ser analisados à luz desta nova questão. Nas Cortes de Lisboa de 1371, enquanto se queixavam da especulação dos preços praticada pelos poderosos do reino, os povos admitem que vendiam o pão e o vinho por valores superiores àqueles que eram impostos pelas leis de almotaçaria ${ }^{79}$. No ano seguinte, nas Cortes do Porto de 1372, nos Capítulos Especiais de Lisboa, é relatado um caso que confirma em toda a linha a premissa enunciada neste parágrafo. Segundo os procuradores municipais, alguns comerciantes, nomeadamente padeiras e carniceiros, vendiam pão e carne, no interior da cidade, fora dos locais estipulados para este efeito, fugindo, portanto, à taxação imposta pelo concelho. De acordo com esta queixa, os jurados e almotacés do lugar procuravam corrigir este gravame, sem conseguirem, no entanto, obter qualquer sucesso nos seus intentos, pois as ameaças recebidas provocavam, naqueles oficiais, «medo E reçeo» de eventuais agressões. Deste modo, as padeiras e os carniceiros conseguiam influenciar os preços praticados nos mercados lisboetas, levando a que as gentes da cidade enfrentassem dificuldades, pois os produtos escoavam rapidamente nas praças e carniçarias onde deveriam ser vendidos pelos comerciantes. A resposta de D. Fernando foi dura: o monarca ordenou que aqueles que vendessem fora das normas estipuladas deveriam ser «estranhados» e açoitados pela cidade, demonstrando, assim, que esta questão possuía uma gravidade significativa ${ }^{80}$.

\section{Crises agrárias e fomes: repensar os seus conceitos}

A guerra representava, portanto, um fenómeno que poderia conduzir a períodos de carestia agrícola, cujo epicentro facilmente provocava crises de produção e de abastecimento nas principais cidades do reino. No encalço destas sobrevinham as fomes. Crises e fomes. Conceitos demasiado latos e abstratos, com os quais devemos ter máxima cautela: o que são crises agrárias?, o que são fomes? Oliveira Marques

\footnotetext{
${ }^{79}$ Cortes Portuguesas: Reinado de D. Fernando I (1367-1383)..., vol. I, art. ${ }^{\circ} 70^{\circ}$, p. 48.

${ }^{80}$ Cortes Portuguesas: Reinado de D. Fernando I (1367-1383)..., vol. I, p. 108.
} 
escrevia, em 2001, que Portugal, no século XIV, era um reino em trânsito, que passava «de uma época estável e tradicional para outra de crise que não foi, aliás, una, desenvolvendo-se em crises várias, parcelares no tempo e no espaço, com formas várias também, mais ou menos acentuadas e actuantes de acordo com décadas e locais». Assim, após um momento de grande depressão demográfica, provocado pela Peste Negra, a população do reino estava fortemente debilitada, pelos surtos epidémicos, pelas guerras e pelas fomes ${ }^{81}$.

Historiadores internacionais têm analisado a história económica medieval partindo de novas perspetivas, levando-os, portanto, a repensar algumas das ideias comummente aceites sobre as crises do século XIV. O trabalho de Paolo Malanima, publicado em 1995, em Itália, merece ser destacado ${ }^{82}$. Em síntese, este autor procura compreender a evolução da economia europeia entre o século X e 1820 partindo de uma variável diferente, ou seja, a capitação do produto, utilizando os exemplos de Inglaterra, Países Baixos, Espanha, Itália, França e Alemanha, para representar a Europa do Norte, do Centro e do Sul. Ao converter o produto agrícola num índice contemporâneo ${ }^{83}$, este autor atinge conclusões interessantes: «do século X à Peste Negra registou-se um progresso lento, com razoável produção agrícola, que decresce nos finais do século XIII mas é compensada pelo aumento da produção industrial e dos serviços. No geral, a evolução da capitação do PIB entre 1000 e 1800 passaria por três períodos longos: um de progresso moderado (séculos X ao início do século XIV); um de estagnação, de cerca de cinco centúrias, e finalmente o grande take-off do início do século XIX». Para além disso, Malanima defende que podemos observar uma crise na Idade Média tardia e um crescimento no século XVI se tivermos em consideração a análise do produto agregado.

81 MARQUES, A. H. de Oliveira - "O Tempo das Crises". in Memória de Portugal - O Milénio Português. Ed. de Roberto Carneiro e Artur Teodoro de Matos. Lisboa: Círculo de Leitores, 2001, p. 166.

${ }^{82}$ MALANIMA, Paolo - Economia Preindustriale. Mille Anni: Dal IX el XVIII Secolo. Milão: Bruno Mondadori, 1995.

${ }^{83}$ A paridade de poder de compra tal como era calculada em 1990. DUARTE, Luís Miguel - "«Tomar O Pão Dos Coitados»»."..., p. 243.

Medievalista online № 18| Julho - Dezembro 2015 @ IEM - Instituto de Estudos Medievais 24 www2.fcsh.unl.pt/iem/medievalista 
No entanto, se considerarmos o produto per capita, então, a crise poderá ser encontrada na centúria de Quinhentos ${ }^{84}$.

Outro trabalho de referência é o de Stephan R. Epstein ${ }^{85}$. Este autor junta-se àqueles que têm uma visão otimista sobre a Idade Média Tardia e fala de uma crise de integração. «Uma integração operada desde logo pelos estados nascentes ou em franco reforço, mas que não teria ainda assim permitido baixar os custos de transacção; para isso foi essencial o desenvolvimento de instituições e práticas políticas e judiciais - a ligação entre as dimensões política e institucional e a económica é talvez a mais estimulante sugestão». Neste sentido, é evidenciada a importância das economias regionais (nas quais é dada uma importância acentuada ao nível regional da análise e ao reconhecimento das diferenças regionais existentes), do comércio marítimo e terrestre de curto e médio alcance, «desvalorizando as responsabilidades do mais visível trato marítimo de longa distância na economia tardomedieval. As suas propostas, elaboradas a partir da sua investigação sobre a península italiana, e cuja validade para outras regiões europeias deve ser testada caso a caso, renovam totalmente o questionário de partida para a consideração dos séculos finais da Idade Média» ${ }^{86}$.

Com base nesta contextualização, acredito, portanto, que é ao nível regional que podemos responder a estas questões. Sempre que se analisa uma economia préindustrial percebe-se que são frequentes as crises de abastecimento de cereal nas grandes cidades. Em relação a Barcelona e a toda a área envolvente, por exemplo, Claude Carrère defendeu que apenas nos bons anos agrícolas o trigo chegaria para a procura $^{87}$. Valência, por sua vez, encontrava-se numa situação similar. Ainda assim, no interior de Aragão o trigo era produzido. No entanto, as deficientes condições das vias

\footnotetext{
${ }^{84}$ DUARTE, Luís Miguel - “«Tomar O Pão Dos Coitados».”..., pp. 242-243.

${ }^{85}$ EPSTEIN, Stephan R - An Island for Itself. Economic Development and Social Transformation in Late Medieval Sicily. Cambridge: Cambridge UP, 1992.

${ }^{86}$ DUARTE, Luís Miguel - “«Tomar O Pão Dos Coitados».”..., p. 243.

87 CARRÈRE, Claude - Barcelone, Centre économique à L'époque des Difficultés. Paris: De Gruyter Mouton, 1967, pp. 326-342.
}

Medievalista online № $18 \mid$ Julho - Dezembro 2015 ๑ IEM - Instituto de Estudos Medievais 25 www2.fcsh.unl.pt/iem/medievalista 
terrestres impossibilitavam o seu transporte para as cidades costeiras ${ }^{88}$. Com base no que escrevi, considero que devem ser evitadas, sobretudo, as generalizações abusivas, pois quando «Oliveira Marques insistiu, na sua clássica Introdução à História da Agricultura, na escassez crónica de cereais no Portugal medievo, não poderia estar a generalizar ao país uma situação muito sentida em Lisboa e, em menor medida, no Porto?» ${ }^{89}$

Trabalhos recentes sugerem que se mantenha esta questão em aberto. Oliva Ferrer escreveu, sobre o mundo rural castelhano do século $\mathrm{XV}$, que as análises globais demonstram insuficiências na utilização de asserções generalistas, as quais revelam uma incapacidade em compreender o facto de a economia agrária medieval sustentar amálgamas complexas de produções de subsistência e de relações comerciais ${ }^{90}$. Filipe Themudo Barata notou que as exportações portuguesas de cereais e de vinho para o exterior dependiam, acima de tudo, dos bons anos agrícolas. Por vezes, nos menos bons, era possível para algum mercador colocar trigo no estrangeiro, lucrando certamente muito com isso, caso este conseguisse fugir às prescrições legais ${ }^{91}$. Apesar de Oliveira Marques já ter apontado para estas oscilações produtivas ${ }^{92}$, dados recentes podem ajudar a comprovar este cenário. Segundo Themudo Barata, Pegolloti apontava, em meados do século XIV, Lisboa como um local onde era possível comprar e vender trigo. Mais frequentes são, ainda assim, as menções ao transporte de trigo de Portugal para o Ocidente mediterrânico. Através de cartas de segurança, entre outras fontes, é possível observar a exportação de trigo e de cereais, durante vários anos, para Valência, Barcelona, para várias cidades italianas e até para Terras de Mouros. Ainda assim, conclui Filipe Themudo Barata, apesar de se conhecerem registos de exportação

88 BARATA, Filipe Themudo - Navegação, Comércio e Relações Políticas: os Portugueses no Mediterrâneo Ocidental (1385-1466)..., p. 108.

89 DUARTE, Luís Miguel - “A História Económica do Portugal Medieval (Sugestões para uma recuperação)". in VIII Congreso de la Asociación Española de Historia Económica. Santiago de Compostela: Universidade de Santiago de Compostela, 2005, p. 11.

${ }^{90}$ OLIVA HERRER, Hipólito Rafael - "El mundo rural en la corona De Castilla en la Baja Edad Media: Dinamicas socioeconomicas y nuevas perspectivas de analisis"..., pp. 310-31.

91 BARATA, Filipe Themudo - Navegação, Comércio e Relações Políticas: os Portugueses no Mediterrâneo Ocidental (1385-1466)..., p. 109.

92 Cf.: MARQUES, A. H. de Oliveira - Introdução à História da Agricultura em Portugal: a questão cerealifera durante a Idade Média. $3^{\mathrm{a}}$ ed. Lisboa: Edições Cosmos, 1978.

Medievalista online № 18| Julho - Dezembro 2015 @ IEM - Instituto de Estudos Medievais 26 www2.fcsh.unl.pt/iem/medievalista 
portuguesa de trigo, as fontes parecem traduzir uma maior incidência para a importação deste produto para Portugal ${ }^{93}$. Isto mesmo é descrito por um documento interessante. Em 1414, numa altura em que a cidade de Lisboa ainda lambia as feridas provocadas pelos difíceis anos de guerra, os procuradores deste concelho movem uma queixa a D. João I. Segundo estes homens, o pão, em Terra de Mouros, tinha por estes tempos uma «grande uallia». Os navios portugueses que aportavam na Flandres, na Bretanha e em Inglaterra eram fretados aos mestres portugueses, pelos mercadores estrangeiros, com objetivo de levar pão a Terra de Mouros. Assim, esta ação, «he aazo e cajom de nom vijr pam a estes nossos regnos». D. João I, após ouvir esta queixa, toma medidas bastante duras: ordena que seja proibido o envolvimento de qualquer senhor, mestre e marinheiro português no frete de navios que levem pão, castanhas, avelãs, nozes, entre outros mantimentos, bem como armas (lanças, dardos, espadas, solhas, bacinetes, cotas de malha, bestas), ferro e aço, a qualquer Terra de Mouros. A punição para quem incumprisse? A ameaça de pena de morte ${ }^{94}$ ! Se esboçarmos breves raciocínios em torno deste documento, facilmente podemos atingir algumas conclusões. Em primeiro lugar, a falta de pão em alguns lugares do reino poderia ser motivada pelo deslocamento de navios que carregavam este produto para portos financeiramente mais atrativos, interrompendo assim uma estreita articulação entre a produção interna e a aquisição em mercados externos, diminuindo a oferta deste produtos nas grandes cidades, onde se destacava Lisboa, no caso português. Para além disso, o facto de em Terras de Mouros a "valia do pão" ser bastante superior àquela que era praticada em Lisboa, pode significar que os preços do trigo estavam deflacionados na capital do reino, justificando, assim, uma maior presença deste produto nos mercados da cidade. De resto, esta suposição é confirmada pelos registos de preços conhecidos ${ }^{95}$.

93 BARATA, Filipe Themudo - Navegação, Comércio e Relações Políticas: os Portugueses no Mediterrâneo Ocidental (1385-1466)..., pp. 109-11.

${ }^{94}$ Chancelarias Portuguesas: D. João I, ed. cit., vol. III, t. 3, doc. 1078, pp. 162-163.

${ }^{95}$ Cf.: FERREIRA, Sérgio - Preços e Salários em Portugal na Baixa Idade Média. Porto: Dissertação de Mestrado apresentada à Faculdade de Letras da Universidade do Porto, 2007, pp. 34-35; VIANA, Mário "Alguns Preços de Cereais em Portugal (séculos XIII-XVI)". in Arquipélago. História. Ponta Delgada. 12 (2008), p. 217. 
Em síntese, tendo em consideração aquilo que escrevi, devemos ser cuidadosos quando falamos em crises agrárias. Ao conceito de carestia agrícola necessitamos associar sempre uma data, um local concreto e devemos atentar, acima de tudo, na sua causa, seja ela motivada pela perturbação dos mecanismos de comercialização ou de armazenamento devido a medidas políticas ou administrativas, provocada por más $\operatorname{colheitas}^{96}$, estimulada pela especulação de preços ou, por fim, movida pelas devastações nos campos de produção e nos circuitos de fornecimento provocados pela guerra. Nem sempre os motivos para a carestia agrícola estavam relacionados com a improdutividade dos solos. Por vezes, uma colheita poderia ser simplesmente devastada pela presença de animais, como parece ter acontecido com os porcos monteses ${ }^{97}$ ou os $\operatorname{veados}^{98}$. Existe, aliás, um documento muito pertinente que ajuda a repensar esta ideia generalizada sobre a escassez crónica de cereal em todo o reino. Em 1386, três mercadores, Vasco Martins, morador em Santarém, Joane Anes e Afonso Rodrigues, moradores em Setúbal, decidiram fretar ao mestre, João Ramalho, o baixel a que chamavam de Santiago, pelo valor de 1.140 libras e 171 soldos. Como podemos observar através deste valor avultado, o comércio abria portas à existência de funções lucrativas que lhe estavam diretamente associadas, como é o caso dos fretamentos marítimos e dos agentes envolvidos nestes mecanismos mercantis ${ }^{99}$. Prosseguindo a narrativa, na embarcação seriam carregados 57 moios de pão (contendo 64 alqueires em cada um $)^{100}$; tratava-se de cerca de 35.842 litros de pão ${ }^{101}$ ! Números verdadeiramente impressionantes para uma cidade do reino que curava feridas recentes provocadas pela guerra. Note-se também que neste ano os preços de trigo no sul de Portugal

${ }^{96}$ DUARTE, Luís Miguel - “«Tomar O Pão Dos Coitados».”..., p. 248.

${ }^{97}$ Cortes Portuguesas: Reinado de D. Fernando I (1367-1383)..., vol. I, art. ${ }^{\circ} 12^{\circ}$, p. 16, e p. 94, art. $^{\circ} 15^{\circ}$. ${ }^{98}$ DUARTE, Luís Miguel - “«Tomar O Pão Dos Coitados».”..., p. 255.

99 Cf. BARATA, Filipe Themudo - Navegação, Comércio e Relações Políticas: os Portugueses no Mediterrâneo Ocidental (1385-1466)...; BARROS, Amândio - Porto: a construção de um espaço marítimo nos alvores dos tempos modernos... Para além destes, encontra-se em fase de publicação um artigo da minha autoria com o título "De Lisboa rumo ao reino: Fretamentos e fretadores nos séculos XIV e $X V^{\prime \prime}$.

${ }^{100}$ Descobrimentos Portugueses..., supl. ao vol. I, doc. 50, p. 69.

101 Os cálculos são simples: cada moio de pão contém 64 alqueires, conforme refere o documento. Admitindo o valor de 9,8251 litros proposto por Luís Seabra Lopes por cada alqueire, para este espaço temporal, estariam naquela embarcação, em rigor, cerca de 35.841,9648 litros de pão. LOPES, Luís Seabra - "A cultura da medição em Portugal ao longo da História". in Educação e Matemática. Lisboa. 84 (2005), p. 42-48.

Medievalista online № 18| Julho - Dezembro 2015 ๑ IEM - Instituto de Estudos Medievais 28 www2.fcsh.unl.pt/iem/medievalista 
encontravam-se particularmente inflacionados. Existem registos sobre preços fixados em 80 soldos na Golegã ${ }^{102}$ e em Santarém ${ }^{103}$. Em Lisboa, por sua vez, dois anos antes (1384), o valor do trigo encontrava-se em valores semelhantes (80 soldos). Admitindo que estes valores representavam uma soma recorrente nas transações do alqueire de trigo, em Lisboa, em 1386, os 3 mercadores encontraram uma oportunidade de negócio muito lucrativa. Trazendo trigo do Porto, localidade onde aparentemente, por estes tempos, este produto não rareava, estes homens procuravam vender este produto em mercados que pagavam muito dinheiro por ele, qualquer coisa como 291.840 soldos pela totalidade do carregamento! Este documento corrobora as queixas dos povos nas Cortes de Lisboa de 1371, quando afirmavam «que mujtos logares de nosso Senhorio ssom mjnguados per esta guerra de pam gaados e doutras cousas que am mester pera sseus mantijmentos E emvijam nas comprar pelas terras e nom as podem auer por dinheiros pelas defesas e posturas e sisas muj descomunaaes que os com//çelhos poeem antre sy cada huũ em sseus logares por lhe nom leuarem as viandas pera fora assij que muijtos o pasam muj bem e ssom auondados E os outros lazeram muj mal» ${ }^{104}$. Ou seja, muitos concelhos enfrentavam com relativa robustez os momentos de carestia de pão, enquanto outros passavam por grandes dificuldades.

Em relação aos momentos de fomes, de acordo com Vitorino Magalhães Godinho, a interpretação deste termo na documentação medieval merece algum cuidado. Existem dois tipos distintos de fome. O primeiro género, o qual podemos designar de fome biológica, era, na prática, aquele que levava à subnutrição e consequentemente à morte ${ }^{105}$. Durante o cerco de Lisboa, em 1384, Fernão Lopes descreve um cenário negro vivido no interior das muralhas. Na cidade, segundo o cronista, «nom avia triigo pera vemder, e se o avia, era mui pouco e tam caro, que as pobres gemtes nom podiam chegar a elle... e começarom de comer pam de bagaço dazeitona, e dos queyjos das mallvas e rraizes dervas... No logar hu costumavam vender o triigo, andavom homeẽs e

\footnotetext{
${ }^{102}$ FERREIRA, Sérgio - Preços e Salários em Portugal na Baixa Idade Média ..., p. 33.

${ }^{103}$ VIANA, Mário - “Alguns Preços de Cereais em Portugal (séculos XIII-XVI)”..., p. 216.

${ }^{104}$ Cortes Portuguesas: Reinado de D. Fernando I (1367-1383)..., vol. I, art. ${ }^{\circ} 65^{\circ}$, p. 46.

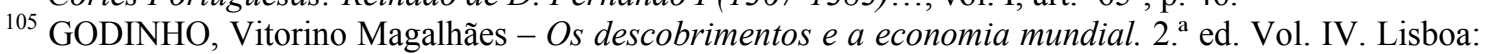
Editorial Presença, 1983, p. 17.
} 
moços esgravatamdo a terra; e sse achavom alguũs graãos de triigo, metiãnos na boca... outros se fartavõ dervas, e beviam tamta agua, que achavom mortos homẽes e cachopos jazer imchados nas praças e em outros logares». Sabemos hoje, e Fernão Lopes evidentemente desconhecia, que o inchaço do abdómen, sobretudo nos "cachopos", é provocado pela desnutrição alimentar. Aquele cronista prossegue, no entanto, com o seu discurso sobre a fome sentida em Lisboa, durante o cerco da cidade, afirmando que alguns homens chegavam ao ponto de «comer as carnes das bestas, e nom soomente os pobres e minguados, mas grãdes pessoas da çidade... Amdavomm os moços de tres e de quatro anos, pedimdo pam pella çidade por amor de Deos, como lhe emssinavam suas madres $(\ldots))^{106}$.

O segundo tipo de fomes pode ser caracterizado por fome cultural, o qual corresponde à falta dos alimentos preferidos pelos hábitos alimentares da época. Assim, quando faltava o pão ou a carne havia fome. Daí que, quando os documentos medievais abordam os anos de fome, não se infira desta asserção a inexistência total de alimentos. Existia, por exemplo, o recurso à caça, ao peixe, aos frutos cultivados e silvestres e aos legumes $^{107}$. A análise ao comércio agrícola português permite facilmente comprovar a existência destes produtos nos mercados nacionais ${ }^{108}$. O simples estudo mais aprofundado sobre a existência de ocupações acumuladas poderia ajudar a responder a algumas questões relacionadas com esta temática. A título exemplificativo, encontrei dados pertinentes num documento da Chancelaria de D. João I. Em 1386, o abade do mosteiro de São João da Alpendorada descreve ao monarca uma situação interessante: o mosteiro possui quatro poços coutados, no rio «Paũha», junto das suas herdades, nos quais os seus lavradores «matam bogas e trujtas». Estes homens tinham, assim, «fectas $<$ pesqueiras aparedados $>$ de paredes em que lançam suas redes e armadilhas em que tomam pescados». No entanto, estas pesqueiras eram devassadas por alguns homens do

\footnotetext{
${ }^{106}$ LOPES, Fernão - Cronica del rei Dom Joham I..., cap. CXLVIII, pp. 269-270.

${ }^{107}$ GODINHO, Vitorino Magalhães - Os descobrimentos e a economia mundial..., vol. IV, p. 17.

${ }^{108}$ Veja-se, por exemplo, BARATA, Filipe Themudo - Navegação, Comércio e Relações Políticas: os Portugueses no Mediterrâneo Ocidental (1385-1466)..., pp. 114-115; CHILDS, Wendy R. - Trade and Shipping in the Medieval West: Portugal, Castile and England. Bélgica: Textes et Etudes du Moyen Âge, 2013, pp. 97-102.
} 
lugar, que «lhes britam as paredes e com suas redes pescam em elles contra suas vontades e dos dictos lauradores». O monarca corrige a situação ${ }^{109}$.

\section{As causas da Lei das Sesmarias: a Peste Negra de 1348 e as Guerras Fernandinas?}

Em suma, vimos que a guerra travada pela Coroa portuguesa durante os anos em estudo alimentou vários problemas. $\mathrm{O}$ rastilho da destruição das terras cultiváveis era, em alguns casos, verdadeiramente incontrolável. As dificuldades que acompanhavam estes acontecimentos não resultavam apenas na devastação de produções agrícolas e dos seus solos. Como foi observado, os homens, aqueles que eram os principais atores da produção agrícola, ficavam sujeitos a uma série de privações e de condicionalismos.

Este filme que narrei representa um certo déjà-vu de um tema bastante conhecido da historiografia portuguesa. O cenário que descrevi obriga-me a abordar a interpretação que vem sido feita pela historiografia portuguesa acerca da promulgação da Lei das Sesmarias, em 1375, por D. Fernando. Esta legislação sobre a agricultura, integrada num conjunto de leis que procuravam proteger e fomentar o comércio, tentou, segundo a historiografia, corrigir o problema de falta de mão-de-obra que grassava no reino português. Para atingir este objetivo a Monarquia procurou fixar o trabalhador na terra, mesmo contra a sua vontade, recorrendo às autoridades do rei e dos poderes locais. Esta deserção dos campos aconteceu, segundo os próprios legisladores, devido aos problemas de abastecimento do reino e aos aumentos de salários ${ }^{110}$. Estas dificuldades -

${ }^{109}$ Chancelarias Portuguesas: D. João I, ed. cit., vol. I, t. 3, doc. 1193, pp. 132-133.

110 As dificuldades sentidas com o elevado custo da mão-de-obra no período pós-Peste Negra são comprovadas por alguns trabalhos consagrados: RODRIGUES, Ana Maria S. A. - Torres Vedras. A Vila e o Termo nos Finais da Idade Média. Lisboa: Fundação Calouste Gulbenkian / JNICT, 1995, p. 407; COELHO, Maria Helena da Cruz - O Baixo Mondego nos finais Da Idade Média, $1^{\mathrm{a}}$ ed.. Coimbra: Faculdade de Letras da Universidade de Coimbra, 1983, pp 634-642; GONÇALVES, Iria - O Património do Mosteiro de Alcobaça nos Séculos XIV e XV. Lisboa: Universidade Nova de Lisboa. Faculdade de Ciências Sociais e Humanas, 1989, pp. 150-154. No entanto, esta não era uma situação desconhecida para os senhores das terras que contratavam assalariados. É necessário ressalvar que, em 1340, conforme Oliveira Marques frisou, já existiam queixas sobre os altos salários pedidos pelos trabalhadores.

Medievalista online № 18| Julho - Dezembro 2015 @ IEM - Instituto de Estudos Medievais 31 www2.fcsh.unl.pt/iem/medievalista 
prossegue a historiografia - derivam sobretudo da grande mortandade sentida em Portugal após a Peste Negra de $1348^{111}$, resultando numa sequência clássica: razia brutal na população, falta de mão-de-obra, campos abandonados, migrações internas e fuga para as cidades, baixa produção agrícola e carestia do cereal ${ }^{112}$. Assim, a Lei das Sesmarias procurava dar resposta às consequências económicas e aos custos sociais deste acontecimento, os quais «apenas foram perceptíveis em toda a sua extensão, em muitos lugares da Europa, para a geração contemporânea de D. Fernando» ${ }^{113}$.

No entanto, creio que o cenário que foi descrito ao longo deste artigo encontra paralelismos com o quadro que é narrado pela Lei das Sesmarias ${ }^{114}$. Como tal, sem negar o importante papel desenhado pela depressão demográfica que se seguiu ao surto epidémico de 1348, julgo que é sensato repensar a subvalorização da historiografia portuguesa em relação ao papel das Guerras Fernandinas no impulso da criação da Lei das Sesmarias. Entre o início do reinado de D. Fernando e a data de promulgação desta legislação passaram apenas 8 anos. Houve guerra em metade destes anos, entre 13691370 e, acima de tudo, entre 1372-1373, período que correspondeu à fase mais dura dos conflitos com Castela. O regresso da paz e o fim das hostilidades não garantia obrigatoriamente o restabelecimento a curto-prazo da produção e a regularização dos circuitos de abastecimento de géneros. Apesar de a guerra não destruir a fertilidade dos campos, poderia dificultar a produtividade a curto-prazo, pois era necessário que os lavradores voltassem para as terras e que adquirissem sementes e animais, que reconstruíssem os estábulos e os celeiros das explorações agrícolas e pecuárias, para além de se verem obrigados a substituir as alfaias, as carroças e os carros destruídos ou requisitados e nunca devolvidos. Em pior situação estariam os casos em que era necessário esperar, por vezes anos, para que os solos, desgastados com a guerra,

MARQUES, A. H. de Oliveira - Introdução à História da Agricultura em Portugal: a questão cerealifera durante a Idade Média..., pp. 257-258.

${ }_{111}$ RAU, Virgínia - Sesmarias Medievais Portuguesas. Lisboa: Universidade de Lisboa, 1946, pp. 62-67.

${ }^{112}$ MARQUES, A. H. de Oliveira, Portugal na Crise dos Séculos XIV e XV. Vol. IV da Nova História de Portugal. Lisboa, Editorial Presença, 1989, pp. 19-32.

${ }^{113}$ GOMES, Rita Costa - D. Fernando..., p. 120.

${ }^{114}$ Note-se que não é meu objetivo discutir o conteúdo desta lei, o qual implica um estudo aprofundado, que mereceria, por si só, a redação de um artigo (talvez num futuro próximo...). Posto isto, declaro que apenas ambiciono discutir as causas que levaram à promulgação desta legislação.

Medievalista online № 18| Julho - Dezembro 2015 @ IEM - Instituto de Estudos Medievais 32 www2.fcsh.unl.pt/iem/medievalista 
voltassem a $\operatorname{produzir}^{115}$, pois até mesmo a obtenção de estrume podia ser dificultada, uma vez que muito do gado que o produzia estava morto ou foi simplesmente roubado $^{116}$, levando a uma forte inflação do seu preço. Tendo isto em consideração, «o espaço de tempo que podia demorar até que uma seara, uma vinha ou um olival voltasse a ser produtivo e rentável podia ser demasiado longo e trazer, por isso, a ruína de muitos homens e mulheres cuja subsistência dependia da sua produção e, em último caso, trazer o abandono dos campos e a desertificação» ${ }^{117}$. O destino desta gente era, não raras vezes, o refúgio na cidade, aparentemente mais segura aos raides inimigos, enquanto acalentavam a esperança de encontrarem melhores condições de trabalho ${ }^{118}$. De resto, a teoria que avanço parece estar em estreita relação com as queixas dos procuradores do concelho de Silves, em 1372, nas Cortes Especiais de Leiria. Segundo estes homens, «em no tempo que as gentes eram mais no mundo que ora som a dicta cidade nom era tam pobrada per como aa dicta cidade e muro compria E que depois per a pestellença grande que foe E outrossy por terremotos e outros aujamentos de guerra e $\mathrm{d}$ armaçam de gallẽes que a dicta cidade era ora mais despobrada e que poer qual e que per qual acerca he $(\ldots){ }^{119}$. Esta é, de resto, a única menção nos capítulos de Cortes de D. Fernando ao despovoamento provocado pelas pestilências, enquanto se multiplicam aqueles que culpabilizam a guerra pelo decréscimo populacional. Embora seja verdade que os procuradores dos concelhos, sobretudo raianos, aperfeiçoaram uma retórica habilidosa ao longo de décadas ameaçando com a possibilidade de desertificação dos seus lugares

115 MARTINS, Miguel Gomes - "Abastecer as cidades em contexto de guerra: o cerco de Lisboa de 1384 "..., p. 136.

${ }^{116}$ MARTINS, Miguel Gomes - A Arte da Guerra em Portugal (1245-1367)..., p. 526.

${ }^{117}$ MARTINS, Miguel Gomes MARTINS - "Ficou aquela terra estragada quemaravylhosa cousa era de ver. Guerra e paisagem no Portugal medieval (1336-1400)". in GONÇALVES, Iria (coord.) - Paisagens Rurais e Urbanas - Fontes, Metodologias, Problemáticas. Actas das Segundas Jornadas. Lisboa: Centro de Estudos Históricos da Universidade Nova de Lisboa, 2006, p. 132.

118 MARTINS, Miguel Gomes - A Arte da Guerra em Portugal (1245-1367)..., p. 524. Isto mesmo é descrito numa composição do trovador Martim Moxa: "perde[n]-se [lavradores nas cidades], / porque non an omen que os defenda: / nen lavran vinhas nem lavran erdades, / nem ar tẽe per u se pagu'a renda. / Perden- 'as onras [sen mais cousimento]". Cantigas d'Escarnho e de Mal Dizer dos Cancioneiros Medievais Galego-Portugueses. Ed. crítica e vocabulário de Manuel Rodrigues Lapa. Lisboa: João Sá da Costa, 1995, cantiga 277, p. 183.

${ }^{119}$ Cortes Portuguesas: Reinado de D. Fernando I (1367-1383)..., vol. I, p. 137. 
com o objetivo de verem mais facilmente aprovados os pedidos que moviam ${ }^{120}$, é extremamente provável que os fantasmas da guerra tivessem tido uma grande responsabilidade na promulgação da Lei das Sesmarias, em 1375, pois «quando começou a guerra (...) naceo outro mundo novo muito contrairo ao primeiro»» ${ }^{121}$.

\section{Conclusões}

Para rematar este longo percurso, resta-me sintetizar em algumas linhas aquilo que escrevi nas páginas anteriores:

Em primeiro lugar, concluí que quando a guerra trilhava o seu curso pelo reino sobrevinham, então, dificuldades de produção e de abastecimento no território, algo que se acentuava nos maiores centros urbanos, como era o caso de Lisboa. As múltiplas contrariedades que foram descritas (destruição de instrumentos de produção, devastação de campos agrícolas, interrupção de circuitos de abastecimento, etc.) não se manifestavam em resultado de danos colaterais provocados pelos enfrentamentos bélicos. Pelo contrário, na Idade Média, os não-combatentes (com especial destaque para os lavradores), em conjunto com os seus bens e propriedades, representavam um objetivo militar de extrema importância e que devia ser anulado a todo o custo.

Em segundo lugar, indiquei que a especulação de preços nos mercados do século XIV é relatada na documentação manuscrita. Os indivíduos que a patrocinavam usavam recursos diversificados para lucrar no comércio de produtos agrícolas: por um lado, os privilegiados recorriam, por exemplo, ao seu estatuto e à sua própria riqueza para inflacionar o preço dos víveres; por outro lado, os populares incorriam nestas práticas através de outros meios, vendendo, a título exemplificativo, as suas mercadorias fora

${ }^{120}$ COELHO, Maria Helena da Cruz e RÊPAS, Luís Miguel - "As petições dos concelhos do distrito da guarda em cortes e a política transfronteiriça". in Territórios e Culturas Ibéricas. Porto: Campo das Letras, 2005, pp. 131-142.

${ }^{121}$ LOPES, Fernão - Crónica de D. Fernando. Lisboa: INCM - Imprensa Nacional Casa da Moeda, 2009, Prólogo, p. 4.

Medievalista online № 18| Julho - Dezembro 2015 ๔ IEM - Instituto de Estudos Medievais 34 www2.fcsh.unl.pt/iem/medievalista 
dos locais apropriados, por forma a fugirem ao controlo das autoridades municipais; enquanto os primeiros usavam de elementos de autoridade para praticar estes atos, os segundos recorriam com a mesma facilidade a ameaças de violência. Em suma, a especulação de preços demonstra, em toda a linha, a complexidade do comércio agrícola de finais da Idade Média, o qual poderia suscitar lucros muito significativos para os indivíduos que sabiam como aproveitar algumas das fragilidades deste mercado.

Em terceiro lugar, foram repensados os conceitos de crises agrárias e de fomes, procurando contrariar as ideias clássicas sobre a escassez crónica de cereal em Portugal. Como referi, ao conceito de carestia agrícola é obrigatória a associação de uma data, de um local concreto, procurando conhecer a sua causa, seja ela motivada pela perturbação dos mecanismos de comercialização ou de armazenamento, provocada por más colheitas, movida pela especulação de preços ou estimulada pela devastação nos campos de produção e nos circuitos de fornecimento provocados pela guerra. Por sua vez, sobre as fomes, subscrevi a teorização de Vitorino Magalhães Godinho acerca da fome biológica (definindo-se por ser aquela que leva, de facto, à subnutrição e possivelmente à morte) e da fome cultural (caracterizando-se por ser aquela que resulta da falta dos alimentos preferidos pelos hábitos alimentares da época). Neste contexto, julgo ser importante o desenvolvimento de novas investigações cujo objetivo seja o de conhecer a existência de ocupações acumuladas, temática que ajudaria a desmistificar algumas das ideias comummente aceites pela historiografia portuguesa. Isto é, um mau ano agrícola não significaria que um lavrador sucumbisse perante a ausência total de alimentos. Para além do acesso ao mercado, este homem poderia recorrer à caça ou à pesca, conforme demonstrei através de um exemplo referente a esta última atividade.

Por fim, em quarto lugar, a condução da minha narrativa levou-me a repensar a interpretação que vem sido feita pela historiografia portuguesa sobre a promulgação da Lei das Sesmarias, em 1375, por D. Fernando. Isto é, considero que deve ser reconsiderado o papel das duas primeiras Guerras Fernandinas (1369-1370 e 1372-73) na criação desta legislação. Como tal, creio que o cenário desenhado pelos conflitos bélicos, os quais foram narrados ao longo deste texto, encontra muitos paralelismos com o quadro que é descrito pela Lei das Sesmarias. Assim, sem rejeitar o importante papel 
traçado pela depressão demográfica que se seguiu à Peste Negra de 1348, julgo que é sensato reconsiderar a subvalorização excessiva da historiografia portuguesa em relação à responsabilidade das Guerras Fernandinas no impulso de conceção da Lei das Sesmarias.

Recrutar. Produzir. Abastecer: conforme iniciei este artigo, assim o encerro. Entre 1369 e 1400, D. Fernando e D. João I viram-se obrigados a articular com destreza a envolvência do recrutamento militar, com os processos de produção e de abastecimento agrícolas. Isto é, num período marcado por sucessivos enfrentamentos bélicos, a Coroa necessitava de homens para integrar as fileiras da sua hoste. No entanto, este alistamento precisava de ser feito tendo sempre como horizonte presente as necessidades de abastecimento do reino, evitando, assim, que o recrutamento recaísse sobre os lavradores - tarefa que, aliás, nem sempre era conseguida. Porém, não era apenas o recrutamento militar que poderia influenciar as relações económicas e sociais de finais do século XIV. As incursões de soldados inimigos em território nacional levaram, não raras vezes, à criação de períodos de carestia agrícola que dificultavam o abastecimento de algumas cidades do reino. Esta análise permite - repito - contrariar algumas das conceções clássicas da historiografia portuguesa. Assim, julgo ser fundamental que a historiografia portuguesa crie novos campos de pesquisa tendo como base de trabalho a integração da componente militar articulada com a análise à sociedade e aos sistemas de produção e comercialização da Idade Média. A guerra é um elemento de mobilização social e económica: como vimos, enquanto alguns indivíduos conheceram a sua ruína financeira fruto dos conflitos militares, outros beneficiaram de oportunidades de enriquecimento económico através da exploração de um comércio agrícola que se encontrava inflacionado. Em suma, acho que é crucial que qualquer estudo de história económica medieval, o qual esteja evidentemente delimitado por períodos cronológicos marcados por conflitos bélicos, tenha em consideração a trilogia que procurei descrever ao longo deste texto, ou seja, a existência de uma preocupação constante por parte da Coroa em articular o recrutamento militar, a produção e o abastecimento agrícolas do reino.

Ho caminho fica aberto 
a quem mais quiser dizer: tudo o que escreui he certo. non pude mais escreuer por nã ter mais descuberto; sem letras, e sem saber, me fuy naquisto meter, por fazer a quem mais sabe, que o que minguar acabe; pois eu mais não sey fazer.

Garcia de Resende, in Miscelânea

\section{REFERÊNCIAS BIBLIOGRÁFICAS}

\section{Fontes manuscritas}

IAN/TT, Chancelaria de D. Fernando.

\section{Fontes impressas}

Cantigas d'Escarnho e de Mal Dizer dos Cancioneiros Medievais Galego-Portugueses. Ed. crítica e vocabulário de Manuel Rodrigues Lapa. Lisboa: João Sá da Costa, 1995.

Chancelarias Portuguesas: D. João I. Ed. de João José Alves Dias. Vol. I-IV. Lisboa: Universidade Nova de Lisboa, Centro de Estudos Históricos, 2004-2006.

Cortes Portuguesas: Reinado de D. Fernando I (1367-1383). Ed. de A. H. de Oliveira Marques. Vol. I-II. Lisboa: Instituto Nacional de Investigação Científica, 1990.

Descobrimentos portugueses: documentos para a sua história. Ed. de João Martins da Silva Marques. Lisboa: Instituto Nacional de Investigação Científica, 1988. 
LOPES, Fernão - Cronica del rei Dom Joham I. Lisboa: INCM - Imprensa Nacional Casa da Moeda, 1997.

LOPES, Fernão - Crónica de D. Fernando. Lisboa: INCM - Imprensa Nacional Casa da Moeda, 2009.

Ordenações Afonsinas. Lisboa: Fundação Calouste Gulbenkian, 1984.

\section{Estudos}

BARATA, Filipe Themudo - Navegação, Comércio e Relações Políticas: os Portugueses no Mediterrâneo Ocidental (1385-1466). Lisboa: Fundação Calouste Gulbenkian, 1998.

BARATA, Filipe Themudo e HENRIQUES, António Castro - "Economic and Fiscal History". in MATTOSO, José (dir.) - The Historiography of Medieval Portugal. Lisboa: Instituto de Estudos Medievais, Universidade Nova de Lisboa, 2011, pp. 26181.

BARROS, Amândio - "O Porto contra os corsários. (A expedição de 1469)". in Revista da Faculdade de Letras. História. Porto. Vol. III, nº 1 (2000), pp. 11-27.

BARROS, Amândio - Porto: a construção de um espaço marítimo nos alvores dos tempos modernos. Porto: Dissertação de doutoramento em História apresentada à Faculdade de Letras da Universidade do Porto, 2004.

BORRERO FERNÁNDEZ, Mercedes - "El mundo rural y la crisis del siglo XIV. Un tema historiográfico en proceso de revisión". in Edad Media. Revista de Historia. Valladolid. 8 (2007), pp. 37-58.

BOUTHOUL, Gaston - O Fenómeno Guerra. Lisboa: Estúdios Cor, 1966.

CARRÈRE, Claude - Barcelone, Centre économique à L'époque des Difficultés. Paris: De Gruyter Mouton, 1967. 
CASADO ALONSO, Hilario - Señores, Mercaderes y Campesinos. La Comarca de Burgos en la Baja Edad Media. Valladolid: Junta de Castilla y León. Consejería de Cultura y Bienestar Social, 1987.

CASADO ALONSO, Hilario - "Existió la crisis del siglo XIV? Consideraciones a partir de los datos de la contabilidad de la catedral de Burgos". in VAL VALDIVIESO, María Isabel del e MARTÍNEZ SOPENA, Pascual (coord.) - Castilla y el Mundo Feudal. Homenaje al Professor Julio Valdeón. Vol. III. Valladolid: Junta de Castilla y León - Universidad de Valladolid, 2009, pp. 9-25.

CHILDS, Wendy R. - Trade and Shipping in the Medieval West: Portugal, Castile and England. Bélgica: Textes et Etudes du Moyen Âge, 2013.

COELHO, Maria Helena da Cruz - O Baixo Mondego nos finais Da Idade Média, 2 vols., $1^{\text {a }}$ ed.. Coimbra: Faculdade de Letras da Universidade de Coimbra, 1983.

COELHO, Maria Helena da Cruz e RÊPAS, Luís Miguel - "As petições dos concelhos do distrito da guarda em cortes e a política transfronteiriça". in Territórios e Culturas Ibéricas. Porto: Campo das Letras, 2005, pp. 131-42.

DOMINGUEZ, Rodrigo da Costa - Mercadores e Banqueiros: Sociedade e Economia no Portugal dos Séculos XIV e XV. Brasília: Hinterlândia, 2009.

DUARTE, Luís Miguel - “A Marinha de Guerra. A Pólvora. O Norte de África”. in BARATA, Manuel Themudo e TEIXEIRA, Nuno Severiano (dir.) - Nova História Militar de Portugal. Vol. I. Rio de Mouro: Círculo de Leitores, 2004, pp. 290-442.

DUARTE, Luís Miguel - A História Económica do Portugal Medieval (Sugestões para uma recuperação). Comunicação apresentada ao VIII Congreso de la Asociación Española de Historia Económica. Santiago de Compostela: Universidade de Santiago de Compostela, 2005. Disponível em http://www.usc.es/estaticos/congresos/histec05/ b24_duarte.pdf.

DUARTE, Luís Miguel - “«Tomar O Pão Dos Coitados». Para Repensar a Crise do Século XIV em Portugal”. in COSTA, Leonor Freire, DUARTE, Luís Miguel e 
GARRIDO, Álvaro (ed.) - Economia, Instituições e Império: Estudos em Homenagem a Joaquim Romero Magalhães. Lisboa: Almedina, 2012, pp. 241-61.

EPSTEIN, Stephan R -An Island for Itself. Economic Development and Social Transformation in Late Medieval Sicily. Cambridge: Cambridge UP, 1992.

FERREIRA, Sérgio - Preços e Salários em Portugal na Baixa Idade Média. Porto: Dissertação de Mestrado apresentada à Faculdade de Letras da Universidade do Porto, 2007.

GODINHO, Vitorino Magalhães - Os descobrimentos e a economia mundial. 4 vols.,

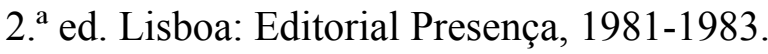

GOMES, Rita Costa - D. Fernando. Mem Martins: Círculo de Leitores, 2005.

GONÇALVES, Iria - O Património do Mosteiro de Alcobaça nos Séculos XIV e XV. Lisboa: Universidade Nova de Lisboa - Faculdade de Ciências Sociais e Humanas, 1989.

HENRIQUES, António Castro - "The Rise of a Tax State: Portugal, 1371-1401", in Ejournal of Portuguese History, vol. 12, nº 1 (2014), pp. 49-66.

IGUAL LUIS, David - “¿Crisis? ¿Qué crisis? El comercio internacional en los renos hispánicos en la Baja Edad Media". in Edad Media. Revista de Historia. Valladolid. 8 (2007), pp. 203-23.

IRADIEL MURUGARREN, Paulino - "La crisis Bajomedieval, un tiempo de conflictos". in IGLESIA DUARTE, J. I. de la (ed.) - XIV Semana de Estudios Medievales de Nájera: Conflictos Sociales, Políticos e Intelectuales en la España de los Siglos XIV y XV. Logroño: Gobierno de la Rioja, Instituto de Estudios Riojanos, 2004, pp. 13-48.

LOPES, Luís Seabra - "A cultura da medição em Portugal ao longo da História". in Educação e Matemática. Lisboa. 84 (2005), pp. 42-48. 
MALANIMA, Paolo - Economia Preindustriale. Mille Anni: Dal IX el XVIII Secolo. Milão: Bruno Mondadori, 1995.

MARQUES, A. H. de Oliveira - Introdução à História da Agricultura em Portugal: a questão cerealifera durante a Idade Média. $3^{\mathrm{a}}$ ed. Lisboa: Edições Cosmos, 1978.

MARQUES, A. H. de Oliveira - "Ideário para uma história económica da Idade Média”. in Ensaios de História Medieval Portuguesa, 2a ed. Lisboa: Vega, 1979, pp. $23-48$.

MARQUES, A. H. de Oliveira - "Cidades Medievais Portuguesas (Algumas Bases Metodológicas Gerais)". in Revista de História Económica e Social. Lisboa. 9 (1982), pp. 1-16.

MARQUES, A. H. de Oliveira, Portugal na Crise dos Séculos XIV e XV. Vol. IV da Nova História de Portugal. Lisboa, Editorial Presença, 1989.

MARQUES, A. H. de Oliveira - "O Tempo das Crises". in Memória de Portugal -O Milénio Português. Ed. de Roberto Carneiro e Artur Teodoro de Matos. Lisboa: Círculo de Leitores, 2001, pp. 164-213.

MARQUES, José - "Devastações biscainhas na quinta da Azóia (1381)". in Revista Portuguesa de História. Coimbra. vol. XXXI, nº 2 (1996), pp. 191-217.

MARTINS, Miguel Gomes - Lisboa e a Guerra (1367-1411). Lisboa: Livros Horizonte, 2001.

MARTINS, Miguel Gomes - "Ficou aquela terra estragada que maravylhosa cousa era de ver. Guerra e paisagem no Portugal medieval (1336-1400)”. in GONÇALVES, Iria(coord.) - Paisagens Rurais e Urbanas - Fontes, Metodologias, Problemáticas. Actas das Segundas Jornadas. Lisboa: Centro de Estudos Históricos da Universidade Nova de Lisboa, 2006, pp. 144-145.

MARTINS, Miguel Gomes - "Abastecer as cidades em contexto de guerra: o cerco de Lisboa de 1384". in ARÍZAGA BOLUMBURU, Beatriz e ÁNGEL SOLÓRZANO, 
Beatriz (Coords.) - Alimentar la ciudad en la Edad Media. Logroño: Instituto de Estudios Riojanos, 2009, pp. 131-151.

MARTINS, Miguel Gomes - “A marca da guerra entre 1250 e 1350”. in MARTINS, Miguel Gomes e MONTEIRO, João Gouveia - As cicatrizes da guerra no espaço fronteiriço Português (1250-1450). Coimbra: Palimage, 2010, pp. 31-71.

MARTINS, Miguel Gomes - A Arte da Guerra em Portugal (1245-1367). Coimbra: Imprensa da Universidade de Coimbra, 2014.

MATTOSO, José - O Monaquismo Ibérico e Cluny. Rio de Mouro: Círculo de Leitores, 2002 .

MELO, Arnaldo - Trabalho e Produção em Portugal na Idade Média: O Porto, c. 1320 - c. 1415. 2 vols. Braga: Dissertação de doutoramento apresentada à Universidade do Minho e à École des Hautes Études en Sciences Sociales, 2009.

MIRANDA, Flávio - Portugal and the medieval Atlantic: commercial diplomacy, merchants, and trade, 1143-1488. Porto: Dissertação de doutoramento em História apresentada à Faculdade de Letras da Universidade do Porto, 2012.

MONTEIRO, João Gouveia - A Guerra em Portugal nos Finais da Idade Média. Lisboa: Editorial Notícias, 1998.

MONTEIRO, João Gouveia - “As feridas da guerra entre 1350 e 1450”. in MARTINS, Miguel Gomes e MONTEIRO, João Gouveia - As cicatrizes da guerra no espaço fronteiriço Português (1250-1450). Coimbra: Palimage, 2010, pp. 73-134.

MONTEIRO, João Gouveia e SILVA, Vasco Jorge Rosa da - "A Vivência da Guerra no Outono da Idade Média”. in BARATA, Manuel Themudo e TEIXEIRA, Nuno Severiano (dir.) - Nova História Militar De Portugal. vol. I. Rio de Mouro: Círculo de Leitores, 2004, pp. 12-44.

MUHAJ, Adrian - Quando todos os caminhos levavam a Portugal: Impacto da Guerra dos Cem anos na vida económica e política de Portugal (Séculos XIV-XV). Lisboa: 
Dissertação de Doutoramento em Letras, especialidade em História Medieval, apresentada à Faculdade de Letras da Universidade de Lisboa, 2013.

OLIVA HERRER, Hipólito Rafael - "El mundo rural en la corona De Castilla en la Baja Edad Media: Dinamicas socioeconomicas y nuevas perspectivas de analisis”. in Edad Media. Revista de Historia. Valladolid. 8 (2007), pp. 295-328.

OLIVA HERRER, Hipólito Rafael - "Reacciones a la crisis de 1504 en el mundo rural castellano". in OLIVA HERRER, Hipólito Rafael e BENITO I MONCLÚS, Pero (eds.) - Crisis de Subsistencia y Crisis Agrarias en la Edad Media. Sevilha: Universidad de Sevilla, 2007, pp. 259-76.

PALERMO, Luciano - Sviluppo Economico e Società Preindustriali. Cicli, Strutture e Congiunture in Europa dal Medioevo Alla Prima Età Moderna. Roma: Viella, 1997.

POLÓNIA, Amélia - A Expansão Ultramarina Numa Perspectiva Local: O Porto de Vila do Conde no Séc. XVI. 2 vols.. Lisboa: Imprensa Nacional - Casa da Moeda, 2007.

PORTELA SILVA, Ermelindo - La región del obispado de Tuy en los siglos XII al XV. Una sociedad en la expansión y en la crisis. Santiago de Compostela: Diputación Provincial de Pontevedra, 1976.

RAU, Virgínia - Sesmarias Medievais Portuguesas. Lisboa: Universidade de Lisboa, 1946.

RODRIGUES, Ana Maria S. A. - Torres Vedras. A Vila e o Termo nos Finais da Idade Média. Lisboa: Fundação Calouste Gulbenkian / JNICT, 1995.

SANTAMARÍA LANCHO, Miguel - "Del concejo y su término a la comunidad de ciudad y tierra: Surgimiento y transformación del señorío urbano de Segovia (siglos XIII-XVI)”. in Studia Historica. Historia Medieval. Salamanca. 2 (1985), pp. 83-116.

SOUSA, Armindo de - As Cortes Medievais Portuguesas. Vol. I. Porto: Instituto Nacional de Investigação Científica - Centro de História da Universidade do Porto, 1990.

Medievalista online № 18| Julho - Dezembro 2015 ๑ IEM - Instituto de Estudos Medievais 43 www2.fcsh.unl.pt/iem/medievalista 
VALDEÓN BARUQUE, Julio - "La Crisis del siglo XIV en Castilla: Revisión del problema". in Revista de la Universidad de Madrid. Madrid. 20 (1972), pp. 161-182.

VALDEÓN BARUQUE, Julio - "Reflexiones sobre la crisis bajomedieval en Castilla". in En La España Medieval. Madrid. 2 (1984), pp. 1047-1060.

VIANA, Mário - “Alguns Preços de Vinho em Portugal”. in Arquipélago. História. Ponta Delgada. 5 (2001), pp. 605-626.

VIANA, Mário - "Alguns Preços de Cereais em Portugal (séculos XIII-XVI)". Arquipélago. História. Ponta Delgada. 12 (2008), pp. 207-279.

\section{COMO CITAR ESTE ARTIGO}

\section{Referência electrónica:}

FERREIRA, Leandro Ribeiro - "Recrutar. Produzir. Abastecer: repensar a produção e o comércio agrícolas em tempo de guerras (1369-1400)". Medievalista [Em linha]. № 18 (Julho - Dezembro 2015). [Consultado dd.mm.aaaa]. Disponível em http://www2.fcsh.unl.pt/iem/medievalista/MEDIEVALISTA18/ferreira1 807.html ISSN 1646-740X.

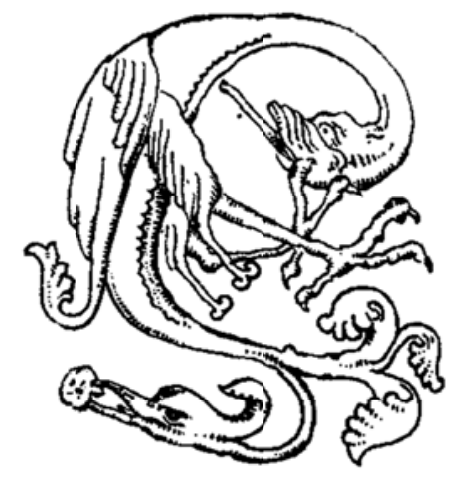

